\title{
High-Resolution Numerical Modeling of Heat and Volatile Transfer from Basalt to Wall Rock: Application to the Crustal Column beneath Long Valley Caldera, CA
}

\author{
M.A. Calogero ${ }^{1}$, E.A. Hetland ${ }^{1}$, and R.A. Lange ${ }^{1}$ \\ ${ }^{1}$ Department of Earth and Environmental Sciences, 1100 N University Ave., \\ University of Michigan, Ann Arbor, MI 48109 \\ Corresponding author: Meredith Calogero (calogero@umich.edu)
}

\section{Key Points:}

- A new high-resolution numerical thermal model is presented, operating over broad spatial ( $\geq 1 \mathrm{~m}$ to $\geq 10 \mathrm{~km})$ and temporal scales $\left(<100\right.$ to $>10^{6}$ years).

- The time scale over which $\mathrm{H}_{2} \mathrm{O}$-rich fluid exsolves from a crystallizing basaltic sill matches that for transient heating of adjacent wall rock.

- Once ambient crust is $\sim 600^{\circ} \mathrm{C}$, large melt fractions in wall rock (granitoid and mafic sills) adjacent to new basaltic sills may form and advect.

This is the author manuscript accepted for publication and has undergone full peer review but has not been through the copyediting, typesetting, pagination and proofreading process, which may lead to differences between this version and the Version of Record. Please cite this article as doi: 10.1029/2018JB016773

This article is protected by copyright. All rights reserved. 


\begin{abstract}
We present a high-resolution numerical model of the thermal evolution of the crustal column beneath Long Valley caldera, California, from which $>800 \mathrm{~km}^{3}$ rhyolite erupted over the last 2.2 Myr. We examine how randomly emplaced basaltic sills of variable thickness $(10,50$, or $100 \mathrm{~m})$ at various depth intervals $(10-25 \mathrm{~km})$ and at variable emplacement rates (5-50 m/kyr) gradually heat the crust and lead to a variably mixed crustal lithology (solidified mafic sills and pre-existing granitoid). We additionally explore the timescales over which dissolved water ( $3 \mathrm{wt} \%)$ in a newly-emplaced basaltic sill exsolves during crystallization and is transferred to adjacent wall rock that is undergoing partial melting. We employ a finite-difference based technique, with variable spatial $\left(\geq 1 \mathrm{~m}\right.$ to $\geq 10 \mathrm{~km}$ ) and temporal $\left(<100\right.$ and $>10^{6}$ years) resolution, that enables dense analysis within and directly adjacent to a newly emplaced sill. Our results show that once ambient crustal temperatures reach $\sim 500-600^{\circ} \mathrm{C}$, subsequent injections of basaltic sills lead to significant partial melting of adjacent wall rock (granitoid and solidified mafic sills) on time scales $\left(10^{1}-10^{2}\right.$ years $)$ that match those of exsolution of $\mathrm{H}_{2} \mathrm{O}$-rich fluid from basaltic sills. Large volumes of fusion (>10\%) during fluidundersaturated partial melting, combined with the pre-existing occurrence of aplite dikes,
\end{abstract}

This article is protected by copyright. All rights reserved. 
facilitates the development of melt-filled fractures that exceed the critical length for selfpropagation. The advection of wall-rock partial melts (with a combined mantle-derived and crustal geochemical signature) to shallower depths will alter both the thermal and compositional profile of the middle-upper crust.

\section{Introduction}

Understanding the origin and evolution of voluminous rhyolitic magmas is of considerable interest because their formation fundamentally re-constitutes and differentiates continental crust, and they may lead to future "super-volcano" eruptions. The largest explosive eruptions ( $>100$ 's $\mathrm{km}^{3}$ ) that have occurred in the United States over the last $1 \mathrm{Myr}$ were high-SiO${ }_{2}$ (75-77 wt\%) rhyolites that erupted from the Long Valley caldera in eastern California (e.g. Hildreth and Wilson, 2007) and the Yellowstone caldera in Wyoming (e.g., Christiansen, 2001), both of which are located in the Basin and Range extensional province of the United States (Supplementary Information; Figure S1).

Several previous studies have addressed the origin of silicic melts by modeling the thermal evolution of the crust as a function of basalt influx (e.g., Shaw, 1980; Huppert and Sparks, 1988; Petford and Gallagher, 2001; Jackson et al., 2003; Dufek and Bergantz, 2005; Annen et al., 2006; Leeman et al., 2008; Karakas and Dufek, 2015; Colón et al., 2018). These studies examined how different rates of basalt emplacement

This article is protected by copyright. All rights reserved. 
heat the crust, leading to the onset of crustal melting, and over what spatial and temporal scales this process might occur. These models additionally track the cooling and crystallization of basaltic intrusions, and thus the geochemical evolution of differentiated mantle melts. Some studies have focused on the emplacement of basalts in the lowermost crust (e.g., Jackson et al., 2003; Dufek and Bergantz, 2005; Annen et al., 2006), which is relevant to subduction-zone settings, whereas others have focused on extensional environments where basalts ascend higher into the middle crust (e.g., Leeman et al., 2008; Karakas and Dufek, 2015; Colón et al., 2018). There is general consensus that both interstitial melts from the basalt intrusions and partial melts of pre-existing crust contribute to the formation of silicic melts, but in a complex, multi-stage process. For example, in the case of the Yellowstone rhyolites, Simakin and Bindeman (2012) and Bindeman and Simakin (2014) have modeled the late-stage, shallow ( $<10 \mathrm{~km})$ re-melting of hydrothermally altered crust that occurred to form many of the low $\delta^{18} \mathrm{O}$ Yellowstone rhyolites. Conversely, Leeman et al. (2008) addressed the initial emplacement of basalt into the middle crust (10-30 km) that produced evolved Yellowstone melts from both preexisting crust and mantle-derived basalt. More recently, Colón et al. (2018) examined the crustal-scale consequences of basalt emplacement/entrapment in the middle crust beneath Yellowstone.

The purpose of this study is to examine how the process of basalt emplacement into the granitoid middle to upper crust beneath the Long Valley caldera, California, 
drives the production of hydrous rhyolitic melts. We build on the crustal-scale approach taken in previous studies (e.g., Dufek and Bergantz, 2005; Annen et al., 2006; Leeman et al., 2008; Karakas and Dufek, 2015; Colón et al., 2018), where the thermal evolution of the entire crustal column in response to basalt influx is simulated. However, this study differs from previous work by examining key processes that occur at relatively short length and time scales (on the order of meters and years, respectively), which requires a numerical model that can achieve such high spatial and temporal resolution while still being able to simulate the entire lithospheric column over a time scale of millions of years.

Our goal in this study is to pay particular attention to the formation of localized partial melts along the wall-rock margins of basaltic sills within the first 10's to 100's of years of their emplacement (e.g., Lim et al, 2012), even when long-term (>1 kyr) ambient temperatures remain sub-solidus (i.e., $<650^{\circ} \mathrm{C}$ ). This is a process that has not yet been quantitatively modeled in the literature and may contribute to the formation, segregation, and ascent of evolved partial melts of a mixed lithology (granitoid and mafic sills), leading to their gradual accumulation in the upper crust. These partial melts will have a combined mantle-derived and crustal geochemical signature. The time scale for the segregation and ascent of these localized partial melts is also considered.

Another focus of this study is the examination of how water is transferred from basaltic sills to partial melts of the crust. One of the defining features of the voluminous 
$\left(>400 \mathrm{~km}^{3}\right.$ ) Early Bishop rhyolite is its high concentration of water ( $\leq 6.5 \mathrm{wt} \%$; Wallace et al., 1999; Anderson et al., 2000). The source of this water cannot be the pre-existing granitoid crust, with a bulk water content $<0.6 \mathrm{wt} \%$ held in biotite and hornblende (Bateman, 1992), and instead must be derived from the Long Valley basalts (e.g., Cousens, 1996), which erupted in close spatial and temporal association with the rhyolites of Long Valley caldera. Understanding this transfer of water is of major importance because melt fraction-temperature (F-T) curves depend strongly on how much water is present.

\section{Tectonic/Geologic setting for numerical modeling}

The numerical simulations presented in this study are designed to be applicable to the Long Valley magmatic system, located in eastern California along the western edge of the Basin and Range province (Supplementary Information; Figure S1b). Between 2.2 and $0.8 \mathrm{Ma}, \sim 100 \mathrm{~km}^{3}$ of rhyolite erupted to form the Glass Mountain complex (Metz and Mahood, 1991; Hildreth, 2004), which was followed by the climactic eruption of the $>600 \mathrm{~km}^{3}$ Bishop Tuff within $\sim 6$ days (Wilson and Hildreth, 1997) to form the Long Valley caldera at $\sim 765 \mathrm{ka}$ (Andersen et al., 2017). Soon after, the eruption of $\sim 100 \mathrm{~km}^{3}$ of rhyolite (named "Early" post-caldera rhyolite by Bailey, 1989) occurred within the caldera between $~ 750-640 \mathrm{ka}$ (Hildreth et al., 2017). Over the last $600 \mathrm{kyr}, \leq 8 \mathrm{~km}^{3}$ of rhyolite have erupted inside the margins of the Long Valley caldera (Hildreth, 2004;

This article is protected by copyright. All rights reserved. 
Simon et al., 2014). A combined volume of $>800 \mathrm{~km}^{3}$ of rhyolite has erupted within the Long Valley volcanic system over the last 2.2 Myr, but over discrete, punctuated time periods characterized by highly variable eruption rates.

This voluminous production of rhyolite was driven by an influx of basalt into the crustal column beneath Long Valley caldera (e.g., Hildreth and Wilson, 2007). Seismic studies indicate a mid-crustal ( 10-20 km depth) low-velocity zone beneath Long Valley (Thurber et al., 2009; Frassetto et al., 2011; Flinders et al., 2018), consistent with the presence of melt and/or fluid. The Long Valley basalts were formed by partial melting of subduction-modified mantle lithosphere (Cousens, 1996), which was triggered by upwelling asthenosphere due to lithosphere delamination beneath the eastern Sierra Nevada (e.g., Manley et al., 2000; Saleeby et al., 2003; Zandt et al., 2004).

\section{Numerical model}

Temperature and melt fraction are solved for using the 1-D non-homogeneous transient thermal diffusion equation:

$$
\rho C_{p} \frac{\partial T}{\partial t}+\rho L \frac{\partial F}{\partial t}=\frac{\partial}{\partial x} k(x) \frac{\partial T}{\partial x}
$$

where $\rho$ is density, $C_{p}$ is specific heat capacity, $L$ is the latent heat, $k(x)$ is thermal conductivity, $T$ is temperature, $F$ is melt fraction, $t$ is time, and $x$ is depth. Temperature and melt fraction are related by a piecewise linear function, $F(T)$, given in general as

This article is protected by copyright. All rights reserved. 


$$
F(T)= \begin{cases}0, & T \leq T_{0} \\ m_{i} T+b_{i}, & T_{i-1} \leq T<T_{i} \\ 1, & T \geq T_{p}\end{cases}
$$

where $T_{0}=T_{\text {solidus }}$ and $T_{p}=T_{\text {liquidus }}$, and $m_{i}$ and $b_{i}$ are the slope and intercept, respectively, for $i \in[1, p]$ segments of the temperature verses melt fraction relationship. Approximating the melt fraction-temperature relationship with $F(T)$ allows for the general relationship

$$
\frac{\partial F}{\partial t}=\phi \frac{\partial T}{\partial t}
$$

where $\phi=0$ if $T<T_{\text {solidus }}$ or $T>T_{\text {liquidus }}$, and $\phi=m_{i}$ otherwise. Using Equation (3), Equation (1) then reduces to

$$
\left(\rho C_{p}+\phi \rho L\right) \frac{\partial T}{\partial t}=\frac{\partial}{\partial x} k(x) \frac{\partial T}{\partial x}
$$

The 1-D compaction and expansion due to solidification and melting, respectively, are approximated by

$$
\frac{d X}{d t}=\varphi X \frac{d F}{d t}
$$

where $X$ is the height of the column of the region undergoing solidification or melting, and $\varphi$ is a scalar representing the percent height change during the phase transition.

Equation (4) is solved in non-dimensional form using a numerical method of lines (MOL) technique on a non-uniform spatial grid and with adaptive time resolution.

Discretizing the spatial coordinate as $x_{j}, j \in[1, N]$, we denote $T\left(x_{j}, t\right)=T_{j}$, which for

This article is protected by copyright. All rights reserved. 
brevity is not written as a function of $t$. The spatial finite difference approximation of Equation (4) is

$$
\frac{\partial T}{\partial t} \simeq \frac{1}{\rho\left(C_{p}+L \phi_{i}\right)} \frac{\left(\frac{T_{j+1}-T_{j}}{x_{j+1}-x_{j}}\right) k_{j+\frac{1}{2}}-\left(\frac{T_{j}-T_{j-1}}{x_{j}-x_{j-1}}\right) k_{j-\frac{1}{2}}}{\frac{1}{2}\left(x_{j+1}-x_{j-1}\right)},
$$

where $k_{j+\frac{1}{2}}=\frac{k_{j+1}+k_{j}}{2}$ and $k_{j-\frac{1}{2}}=\frac{k_{j-1}+k_{j}}{2}$. Equation (6) is numerically integrated at $x_{j}$ using a standard Runge-Kutta method with adaptive time steps (e.g., Dormand, 1996). In the adaptive time-stepping method, the nodal temperatures at each time step are calculated using a proposed time step with both $2^{\text {nd }}$ and $3^{\text {rd }}$ order Runge-Kutta integration schemes. If the maximum difference in the solutions is larger than a specified tolerance (here we use $10^{-5}$ in non-dimensional temperature), the current time step is decreased, and the temperatures for the next time step are recalculated using the two Runge-Kutta schemes and the smaller time step. We continue to decrease the time steps until the $2^{\text {nd }}$ and $3^{\text {rd }}$ order solutions are within tolerance. For each rejected time step, the time step is decreased to 0.9 delT (tolerance/error $)^{1 / 3}$, where error is the maximum absolute difference in the temperature solutions and delT is the previously tested time step (e.g., Noda et al., 2009; Hetland et al., 2010). Once the solutions converge within tolerance, we take the $3^{\text {rd }}$ order solution as the temperatures for the next time step, and the next time step is also 0.9 delT(tolerance/error) $)^{1 / 3}$ (i.e., if the error is larger than 1.372 of the tolerance the time step grows). The minimum nodal spacing controls the stability of each time step, so the solution is always within stability for the larger nodal spacings on the

This article is protected by copyright. All rights reserved. 
non-uniform spatial grid. Using this scheme, the time step decreases when the temperature gradients are high, and then gradually increases after the spatial variations in the temperature gradients subsequently subside. Once the temperatures are calculated at a given time step, the nodal melt fraction is solved for using Equation (2). The melt fraction is then used to calculate the material density, using prescribed densities of the solid and the liquid phases. A first-order discretized form of Equation (5) is integrated to find the compaction (and/or expansion) due to changes in melt crystallization (and/or melt formation).

In all of the simulations presented in this study, the initial domain thickness (from the surface to depth) is $45 \mathrm{~km}$. Over this domain, $\mathrm{N}$ nodes are initially distributed evenly with depth. The material properties of each node are assigned based on their depth, such that if a node is within the boundaries of the lower crust, it is assigned material properties of the lower crust, etc. (Table 1). The first sill is then injected into the model domain (all basalt sills in this study have an initial temperature of $1150^{\circ} \mathrm{C}$ and melt fraction of 1), and then the nodes are adjusted as described below, before solving for the temperatures. Temperatures are calculated at each time step as described above, with additional basalt sills periodically injected into the crust at specified emplacement rates.

After each sill is injected, the domain thickness is increased by the thickness of the sill, and the temperature and melt fraction fields below the sill are advected downward. With each emplacement, new nodal positions are calculated using a node 
placement optimization motivated by a moving mesh MOL (MM-MOL) technique (Huang and Russell, 2011). This allows temperatures to be resolved where thermal gradients are high, without overly discretizing regions of the domain with near-linear temperature gradients. In this node adaptation scheme, the spatial resolution is increased in regions of the model domain with high curvature of the temperature field and/or with high melt faction, while node spacing is decreased where the temperature has minimal curvature and there is no melt present. To adapt the node distribution, we use the mesh density function

$$
\delta^{*}=1+\left|\nabla^{2} T\right|^{\frac{1}{4}}+\gamma F,
$$

and solve for optimal nodal spacings that are proportional to $\delta^{*}$, under the constraint of a prescribed minimum node spacing and that the entire domain is covered by nodes. The proportionality factor $\gamma$ is determined such that the computation domain contains a fixed number of nodes (i.e., nodes are not added or removed from the domain). To avoid singularities in the temperature field, we smooth the mesh density function, following the MM-MOL method (Huang and Russell, 2011). Compression (expansion) during crystallization (melting) is then accounted for by perturbing the nodal positions. Finally, the node positions may be slightly perturbed in order to ensure that there is at least one node between all material boundaries, including locations of all past sills. After the node positions are adjusted, the temperature and melt fraction fields, as well as all material parameters, are mapped from the old mesh to the new mesh using a linear interpolation. 
The numerical solution is implemented in Matlab. With 600 total nodes over an initial domain thickness of $45 \mathrm{~km}$, the largest node spacing after a sill injection is about 130 meters, and occurs at the edges of the model domain (close to the surface and the base of the domain). Aside from some resolution tests, the main simulations presented in this study use a minimum spatial resolution of 1 meter, which corresponds to a minimum temporal resolution of about a minute. Using a spatial resolution of at least 5 meters, the smallest time step is $\sim 6$ days. Due to the adaptive time-stepping algorithm, as temperatures diffuse and basalt sills crystallize, temporal resolution increases, and 1000 years after a sill injection, the time step increases to $~ 10$ days and $~ 8$ months, respectively, for 1 and 5 meter minimum spatial resolutions. Simulations of the thermal evolution of the crust after 200 sill injections take 1 and 14 hours for 1 and 5 meter minimum spatial resolutions, respectively, on a circa 2012 desktop workstation. Results from a benchmark simulation of basalt intruding basalt and subsequent cooling is provided in the supplementary information (Figure S2).

\subsection{Model parameters}

An initial $20^{\circ} \mathrm{C} / \mathrm{km}$ linear geotherm is assumed prior to injection of the basaltic sills, which is consistent with the seismically imaged lithosphere-asthenosphere boundary at $60 \mathrm{~km}$ for the Basin and Range (Levander and Miller, 2012), where a temperature of $1200^{\circ} \mathrm{C}$ marks the lithosphere-asthenosphere boundary (LAB). This relatively cool 
geotherm of $20^{\circ} \mathrm{C} / \mathrm{km}$ is also consistent with the volcanic hiatus in the Long Valley region from 8-4.5 Ma prior to renewed magmatism in the region (Bailey, 1989; Du Bray et al., 2016). The initial crustal composition is assumed to be granitoid from the surface to $32 \mathrm{~km}$ depth, mafic amphibolite from 32-35 km depth, and mantle lithosphere below 35 km (Supplementary Information; Figure S3; Fliedner et al., 2000). The bulk composition used for the granitoid upper crust beneath Long Valley caldera is the average composition of upper crust from Rudnick and Gao (2014). Note that several whole-rock compositions of granitoid from the Sierra Nevada batholith (e.g., Bateman, 1992; Coleman et al., 2012) broadly overlap this average upper crust composition. The composition of basalt used in this study is the average of several Long Valley basalts (50.9 wt $\% \mathrm{SiO}_{2}, 1.5 \mathrm{wt} \% \mathrm{TiO}_{2}, 15.7 \mathrm{wt} \% \mathrm{Al}_{2} \mathrm{O}_{3} ; 8.2 \mathrm{wt} \% \mathrm{FeO}_{\mathrm{T}}, 8.0 \mathrm{wt} \% \mathrm{MgO}, 9.1 \mathrm{wt} \%$ $\mathrm{CaO}, 3.6 \mathrm{wt} \% \mathrm{Na}_{2} \mathrm{O}, 2.2 \mathrm{wt} \% \mathrm{~K}_{2} \mathrm{O}$ and $0.6 \mathrm{wt} \% \mathrm{P}_{2} \mathrm{O}_{5}$ ).

In this study, we initially focus on the emplacement of $5 \mathrm{~km}$ of basalt over a 1 Myr time period, in the form of 50-m thick sills emplaced every $10 \mathrm{kyr}$, into the crust (5 $\mathrm{m} / \mathrm{kyr}$ ). This rate of emplacement was also employed in Leeman et al. (2008) in their thermal model of the crust in response to Yellowstone hot spot magmatism. Different sill thicknesses (10 and $100 \mathrm{~m}$ ) and different time intervals for the emplacement of basalt are additionally explored, leading to different basalt flux rates ( 5-50 m/kyr). Because rhyolite eruption rates out of the Long Valley volcanic system have been highly variable, from $\sim 0.1 \mathrm{~km}^{3} / \mathrm{kyr}$ between 2.2 and $0.8 \mathrm{Ma}$ (Hildreth, 2004) to $>600 \mathrm{~km}^{3} /$ week (Wilson

This article is protected by copyright. All rights reserved. 
and Hildreth, 1997), the effect of variable basalt emplacement rates, including relatively high rates over short time periods (e.g., $50 \mathrm{~m} / \mathrm{kyr}$ for $\leq 100 \mathrm{kyr}$ duration), merits evaluation.

We prescribe a sill emplacement history, either placing sills at the same fixed depth or randomly placing them within a depth interval of the upper crust. Because the tectonic setting is continental extension (and not subduction), basaltic sills are emplaced in the middle (not lower) crust. Note that mid-crustal depth intervals (10-25 km) are broadly consistent with seismic evidence of a mid-crustal sill complex (MSC) beneath the Snake River Plain due to the influx of basalt from the Yellowstone plume (Stachnik et al., 2008; Yuan et al., 2010), which in turn drove the formation of voluminous rhyolite along the Yellowstone hot spot track (Leeman et al., 2008; Colón et al., 2018). In all of the simulations presented in this paper, we assume that all injected basalt sills have an initial uniform temperature of $1150^{\circ} \mathrm{C}$ and are emplaced at fixed time intervals. Nodes within the sills, both the most current and previously solidified sills, are assigned the material properties of basalt (Table 1), and these properties, apart from density, do not change after the sills have solidified. Nodes outside of the sills are assigned material properties of the wall rock (Table 1), relative to the evolving material boundaries with each emplacement.

When sills are emplaced, all material boundaries below the sill margin are moved down by the sill thickness. In the case where sills are inserted at a fixed depth, the top of 
each new sill is at the same depth, and previously emplaced sills are pushed down, creating a contiguous depth range of uniform basaltic composition. When sills are inserted randomly within a depth range, a mixed lithology of alternating granitoid and solidified mafic sills is created. The minimum nodal spacing of $1 \mathrm{~m}$ ensures that a new sill of $50 \mathrm{~m}$ is resolved with 51 nodes as it solidifies. Hereafter, in this text, the term “basaltic sill” refers to a newly emplaced sill that is undergoing crystallization, whereas the term "mafic sill” refers to a previously solidified basaltic sill.

\subsection{Basalt crystallization melt fraction-temperature curve}

We assume an initial temperature of $1150^{\circ} \mathrm{C}$ and an initial water concentration of $3 \mathrm{wt} \% \mathrm{H}_{2} \mathrm{O}$ are used for each basaltic sill. This water content is based on analyses of $\leq 3$ wt $\% \mathrm{H}_{2} \mathrm{O}$ in olivine-hosted melt inclusions of nearby Pliocene-Quaternary basalts erupted along the eastern margin of the Sierra Nevada range (Gazel et al., 2012). To determine the basalt equilibrium crystallization curve with temperature, the thermodynamic model rhyolite-MELTS (Gualda et al. 2012) was used at 0.3 and $0.5 \mathrm{GPa}$. The results are shown in Figure 1a and are parameterized into four linear segments. According to the MELTS calculation, latent heat is distributed nearly linearly as a function of degree of crystallization for this melt composition, which allows total enthalpy (L) to be treated as a linear function of melt fraction. The effect of a non-linear release of latent heat across the liquidus-solidus interval is explored in section 4.1.3.

This article is protected by copyright. All rights reserved. 


\subsection{Melt fraction-temperature (F-T) curves for crustal melting}

Melt fraction versus temperature curves are needed for both solidified mafic sill and granitoid lithologies, and they will each depend strongly on the total amount of $\mathrm{H}_{2} \mathrm{O}$ present. Two end-member $\mathrm{H}_{2} \mathrm{O}$ conditions for each lithology are evaluated: fluid-absent and finite fluid-present (i.e., fixed amount of $\mathrm{H}_{2} \mathrm{O}$ present; not unlimited). In all cases, the F-T curves are calculated using the rhyolite-MELTS thermodynamic model of Gualda et al. (2012) and are plotted in Figure 1.

\subsubsection{Case 1: Fluid-absent mafic sills and granodiorite}

In the first case, it is assumed that after complete crystallization of the basaltic sills in the granitoid crust, approximately one-third $\left(1 \mathrm{wt} \% \mathrm{H}_{2} \mathrm{O}\right)$ of the initial $3 \mathrm{wt} \% \mathrm{H}_{2} \mathrm{O}$ dissolved in the melt is retained in the mineral assemblage in the form of biotite and/or hornblende, which leaves $\sim 2 \mathrm{wt} \% \mathrm{H}_{2} \mathrm{O}$ as a fluid phase under sub-solidus conditions. In this first-case scenario, it is assumed that this fluid phase is completely lost from the sill and surrounding crustal rocks (i.e., through ascent along grain boundaries and/or fractures). This leaves a fluid-absent mafic sill with a bulk $\mathrm{H}_{2} \mathrm{O}$ content of $\sim 1 \mathrm{wt} \%$. Similarly, it is assumed that the surrounding granitoid rock (with a bulk composition similar to average upper crust; Table 1) is also devoid of any fluid phase, and $\mathrm{H}_{2} \mathrm{O}$ is only present in the form of biotite and hornblende ( $<10 \%$ of each phase; Bateman, 1992). In

This article is protected by copyright. All rights reserved. 
this case a total $\mathrm{H}_{2} \mathrm{O}$ content of $\sim 0.5 \mathrm{wt} \%$ is assumed for the granodiorite wall rock. The F-T curves for the fluid-absent mafic sill and granodiorite, with 1 and 0.5 wt $\% \mathrm{H}_{2} \mathrm{O}$ respectively, are calculated using rhyolite-MELTS and are illustrated in Figure 1b. Note that despite the lower $\mathrm{H}_{2} \mathrm{O}$ content, the fluid-absent granodiorite has a higher melt fraction relative to the fluid-absent mafic sill at any given temperature above the solidus. For example, at $800^{\circ} \mathrm{C}$ and $0.3 \mathrm{GPa}$, the granodiorite and mafic sill are predicted to contain $\sim 15$ and $\sim 5 \%$ melt, respectively.

\subsubsection{Case 2: Finite fluid-present mafic sills and granodiorite}

In the second case, it is assumed that during late-stage crystallization of the basaltic sills, $\sim 2 \mathrm{wt} \% \mathrm{H}_{2} \mathrm{O}$ exsolves as a fluid phase and reaches the interface between the sill margin and the granodiorite wall rock. During transient heating of wall rock adjacent to a newly emplaced sill, an initially fluid-present melting curve at the solidus for granodiorite is employed, based on a whole-rock composition of $2 \mathrm{wt} \% \mathrm{H}_{2} \mathrm{O}$, which becomes fluid undersaturated as melt fraction increases. Also shown is an initially fluidpresent melting curve for the solidified mafic sills at the solidus, based on a whole-rock composition of $3 \mathrm{wt} \% \mathrm{H}_{2} \mathrm{O}\left(2 \mathrm{wt} \% \mathrm{H}_{2} \mathrm{O}\right.$ fluid $+1 \mathrm{wt} \%$ in hydrous mineral phases), which becomes fluid undersaturated as melt fraction increases. A comparison of the two initially fluid-present F-T curves (Figure 3c), which become fluid undersaturated with melt fraction, shows that the granodiorite wall rock produces a far greater melt fraction than 
the solidified mafic sills at a given temperature (e.g., $30 \%$ vs. $5 \%$ at $750^{\circ} \mathrm{C}$ and $0.5 \mathrm{GPa}$ ). We use the term "finite fluid-present" to distinguish the F-T curves in Figure 1c (case 2), which are based on a finite (i.e., fixed) amount of water in the system, from F-T curves that are fluid saturated under all melt fraction conditions (i.e., unlimited amount of water available).

\section{Results}

\subsection{Crustal-Scale Thermal Evolution}

We ran simulations with the following parameters varied: (1) sill emplacement style (e.g. fixed versus random emplacement depth); (2) minimum spatial resolution (25, 5, and $1 \mathrm{~m}$ ); (3) non-linear distribution of latent heat in basaltic sills; (4) thickness of sills (10, 50 and $100 \mathrm{~m})$; (5) depth range of sill emplacement; (6) rate of sill emplacement (i.e., different time intervals over which a fixed amount of basalt is emplaced in the crust); and (7) fluid-absent vs. finite fluid-present F-T curves for wall rock (granodiorite and solidified mafic sills). In each of these cases, all other variables were held constant. The goal was to evaluate first-order effects on the thermal evolution of the crust at the kilometer length scale, as well as the resulting proportions of mafic sills and granitoid in the crustal column. Both crustal temperature and the extent of a mixed lithology in the crustal column must first be determined before the extent of any partial melting along the margins of newly emplaced sill can be evaluated.

This article is protected by copyright. All rights reserved. 


\section{$\underline{\text { 4.1.1 Fixed vs. Random Depth Emplacement }}$}

Previous studies have examined both fixed and random emplacement of basaltic sills (e.g., Annen et al., 2006; Leeman et al., 2008). For comparative purposes, we also consider both emplacement schemes. In each simulation, the initial sill temperature $\left(1150^{\circ} \mathrm{C}\right)$ and emplacement rate (50-m sill every $\left.10 \mathrm{kyr}\right)$ are held constant. In the fixeddepth emplacement scheme, new sills are injected with their top surface at 10-km depth, the shallowest depth chosen in Leeman et al. (2008). In the random-depth emplacement scheme, the initial depth range for sill emplacement is $10-15 \mathrm{~km}$, with the upper depth limit held constant at $10 \mathrm{~km}$ and the lower depth limit moved down by the thickness of each new sill after it is emplaced. The simulations were run for 1 Myr in both cases, resulting in $5 \mathrm{~km}$ of basalt added to the crustal column. In the fixed-depth emplacement scheme, the added basalt sills are contiguous, whereas in the random-depth emplacement scheme, a mixed lithology results between $10-20 \mathrm{~km}$ depth, with an average 1:1 ratio of mafic sills to granitoid. The evolution of the thermal profile at $0.25,0.5,0.75$, and $1 \mathrm{Myr}$ for each emplacement scheme is shown in Figure 2. The thermal profiles shown are those $10 \mathrm{kyr}$ after the most recent sill emplacement (i.e. immediately before the next scheduled emplacement of a 50-m sill). For both emplacement schemes, all basaltic sills are fully crystallized after $1 \mathrm{Myr}$ and there are no crustal depths hotter than $725^{\circ} \mathrm{C}$. 
In the fixed-depth emplacement simulation, after $1 \mathrm{Myr}$, the maximum crustal temperature is $\sim 725^{\circ} \mathrm{C}$ and occurs inside the most recently emplaced basalt sill, immediately below 10-km depth (i.e., near the interface with granitoid crust). In this simulation, temperatures are $>600^{\circ} \mathrm{C}$ over $\sim 2$-km thickness of granitoid crust immediately above the contiguous mass of basaltic sills. In contrast, in the random-depth emplacement simulation, after $1 \mathrm{Myr}$, the maximum crustal temperature is $\sim 686^{\circ} \mathrm{C}$, again inside the most recently emplaced basalt sill. However, the amount of granitoid (distinct from mafic sills) heated $>600^{\circ} \mathrm{C}$ is nearly twice as thick at $\sim 4 \mathrm{~km}$. The increase in thickness of granitoid that is heated by the random emplacement of sills reflects the more efficient transfer of heat from the basaltic sills to the surrounding granitoid when the 50m thick sills are spread out throughout the crustal column (e.g., Dufek and Bergantz, 2005). A microscale example of this phenomenon is described in Spera and Bohrson (2018).

\subsubsection{Variation of Minimum Spatial Resolution}

To evaluate the effect of the spatial resolution of our finite-difference model on crustal thermal profiles, we ran the same random-emplacement simulation (i.e., with identical sill history) from Figure 2b, using minimum spatial resolutions of 1, 5, and 25 $\mathrm{m}$. The final temperature profiles over the depth range where most sills were emplaced are shown in Figure 3. For reference, the center of the last sill emplaced is at a depth of 
$16.62 \mathrm{~km}$. After 1 Myr the maximum temperatures in the 25-m and 5-m cases are 19 and $\sim 4^{\circ} \mathrm{C}$, respectively, colder than the 1-m case. The most precise results are obtained with the highest spatial resolution $(1 \mathrm{~m})$, which is used for all simulations presented in this study.

\subsubsection{Varying Distribution of Latent Heat across the Liquidus-Solidus Interval}

In Equation 1, if $\mathrm{F}>0$ then the latent heat $(\mathrm{L})$ is released linearly as a function of

$\%$ crystallization. This is the default case for all simulations presented in the main body of the text. To test whether crustal-scale thermal profiles are sensitive to how latent heat is distributed across the liquidus-solidus interval of basaltic sills, we added an additional step during the Runge-Kutta time-stepping, which adjusts the proportion of latent heat released across the liquidus-solidus interval (Supplementary Information; Figure S4a). In the first test case, $75 \%$ of the latent heat is released in the first $25 \%$ of crystallization, whereas in the second test case, only $25 \%$ of the latent heat is released in the first $75 \%$ of crystallization, and the remaining $75 \%$ of latent heat is released in the last $25 \%$ of crystallization. In all simulations, the same total amount of latent heat is released during crystallization of the basaltic sills, and all other parameters are unvaried, including the random sill emplacement history (same as that in Figure 2b). The resulting thermal profiles at 1 Myr are within $\leq 5$ degrees for all three cases (Supplementary Information;

This article is protected by copyright. All rights reserved. 
Figure S4b), which shows that variations in how latent heat is distributed across the liquidus-solidus interval have a negligible effect on crustal-scale thermal profiles.

\subsubsection{Variation in Thickness of Basaltic Sills}

The effect of varying the thickness of basaltic sills (10, 50 and $100 \mathrm{~m}$ ), which are emplaced at an identical long-term rate (5 km/1 Myr) and initial depth interval (10-15 $\mathrm{km})$, on the crustal-scale thermal profile was also explored. There is no difference in the temperature profile through the crust when 10- and 50-m thick sills are randomly emplaced (Supplementary Information; Figure S5). However, three simulations of random emplacement of 100-m thick sills every 20 kyr were run, producing variable thermal profiles after $1 \mathrm{Myr}$. For one simulation, the thermal profile closely matches those for the 10- and 50-m thick sill emplacement runs, whereas other random sill histories produced higher temperature concentrations at shallower or deeper depths (see Supplementary Information, Figure S5b). The differences in the three 100-m sill thermal profiles is due to the random (and thus varying) emplacements of relatively thicker and fewer basaltic sills into the crustal column, particularly controlled by the final few sill emplacements in each simulation.

\section{$\underline{4.1 .5 \text { Variation of Emplacement Depths and Depth Ranges }}$}

This article is protected by copyright. All rights reserved. 
In order to test the effect of varying the depth ranges over which basaltic sills are emplaced, we ran simulations of random sill emplacements (50 m/10 kyr) over a $1 \mathrm{Myr}$ time interval with variable initial depth ranges: (1) 10-15 km, (2) 15-20 km, and (3) 10$20 \mathrm{~km}$. In each of the three test cases, we ran four realizations of random sill emplacements and took their average thermal profile after 1 Myr (Supplementary Information; Figure S6). In all cases, a total of $5 \mathrm{~km}$ of basalt was emplaced in the respective depth ranges after 1 Myr (final ranges: 10-20 km, 15-25 km, and 10-25 km respectively). In the models where the initial depth range spans $5 \mathrm{~km}$ (10-15 and 15-20 $\mathrm{km}$ ), the final sill:granitoid ratio is $1: 1$, whereas when the initial depth range spans $10 \mathrm{~km}$ (10-20 km), the resulting sill:granitoid ratio is 1:2. The most important observation in Figure S6 is that the depth interval over which basaltic sills are emplaced strongly affects the proportion of mafic sills embedded within the granitoid crust once temperatures reach $\sim 600^{\circ} \mathrm{C}$. In other words, the deeper and broader the initial depth interval of sill emplacement (at a constant rate), the lower the amount of basalt that is required to bring crustal temperatures to $\sim 600^{\circ} \mathrm{C}$.

\subsubsection{Variation of Sill Emplacement Rate}

We next explored the thermal effect of emplacing the same 5-km thickness of basalt over different time intervals (1, 0.5 and $0.1 \mathrm{Myr}$ ). In all cases, the initial depth range is $10-15 \mathrm{~km}$, and after 100 sills are emplaced the average final sill:granitoid ratio is

This article is protected by copyright. All rights reserved. 
1:1 between $10-20 \mathrm{~km}$ depth. The only difference among the three simulations is the frequency with which the 50-m thick sills are emplaced, every 10, 5 and $1 \mathrm{kyr}$, respectively.

The results for these three simulations are compared in Figure 4, using the same sill injection histories shown in Figure 2b (100 total sills). The lowest basalt emplacement rate (5 $\mathrm{km}$ over $1 \mathrm{Myr}$ ) results in a thermal profile that is everywhere $<700^{\circ} \mathrm{C}$, with a maximum temperature of $686^{\circ} \mathrm{C} 10 \mathrm{kyr}$ after the last sill is emplaced. In the second simulation, the same $5 \mathrm{~km}$ of basalt is emplaced in half as much time (500 kyr), and the thermal profile is notably hotter, with $\sim 4 \mathrm{~km}$ of crust reaching temperatures $>700^{\circ} \mathrm{C} 5 \mathrm{kyr}$ after the $100^{\text {th }}$ sill is emplaced, and a maximum at $752^{\circ} \mathrm{C}$. In the third simulation, where 5 $\mathrm{km}$ of basalt is emplaced within $100 \mathrm{kyr}(50 \mathrm{~m} / 1 \mathrm{kyr}), \quad 7.7 \mathrm{~km}$ of crust is heated above $700^{\circ} \mathrm{C} 1 \mathrm{kyr}$ after the $100^{\text {th }}$ sill is emplaced, including $\sim 2 \mathrm{~km}$ in excess of $800^{\circ} \mathrm{C}$; the maximum temperature is $836^{\circ} \mathrm{C}$.

These combined results (Figure 4) show that the time interval over which a fixed amount of basalt is placed into the crust has a notably strong effect on the thermal profile through the crust, as found in previous studies (e.g., Dufek and Bergantz, 2005; Annen et al., 2006; Leeman et al., 2008). Over shorter time intervals, there is insufficient time for the heat from the basaltic sills to diffuse away, allowing the crustal range with a 1:1 basalt:granitoid lithology to attain markedly higher temperatures. Conversely, less basalt 
(3 vs $5 \mathrm{~km}$ ) is required at high vs. low emplacement rates ( $50 \mathrm{vs.} 5 \mathrm{~m} / \mathrm{kyr}$ ) to reach a similar temperature profile in the crust (Figure 4b, dashed).

\subsubsection{F-T Curves for Granitoid Wall Rock: Fluid-Absent vs. Finite Fluid-Present}

The final parameter that we explored is the effect of variable melt-fraction vs temperature curves for the wall rock under fluid-absent (case-1) and finite fluid-present (case-2) conditions. The latent heat of fusion term in Equation (4) during partial melting acts as a heat sink (opposite to the release of heat during basalt crystallization), and hence the choice of the F-T curve for the wall rock can affect crustal-scale thermal profiles. The magnitude of this effect is illustrated in Figure 5 after 100 sill emplacements at two rates, $50 \mathrm{~m} / 10 \mathrm{kyr}$ and $50 \mathrm{~m} / 5 \mathrm{kyr}$ ( 1 and $0.5 \mathrm{Myr}$, respectively). For the same amount of basalt injected into the crust ( $5 \mathrm{~km}$ ), the lower vs. higher emplacement rates heat $\sim 4 \mathrm{vs.} \sim 7 \mathrm{~km}$ of crust above $650^{\circ} \mathrm{C}$ (Figure $5 \mathrm{a}$ ).

In these simulations, there is a marked difference in the amount of partial melt that is formed, depending on which F-T curve is applied to the wall rock (fluid-absent vs. finite fluid-present), examined in Figure 5b. For the lower emplacement rate, the difference in the melting curves leads to the presence ( $\sim 2 \%$ melt) vs. absence of melt. For the higher emplacement rate (i.e. hotter crustal temperatures), the fluid-absent melting curve leads to the formation of less partial melt $(<5 \%)$ across $3.6 \mathrm{~km}$ of crust, whereas the finite fluid-present melting curve leads to the formation of partial melt across $4.5 \mathrm{~km}$ of

This article is protected by copyright. All rights reserved. 
crust, with $>20 \%$ melt present over nearly $3 \mathrm{~km}$. Importantly, the difference in the amount of partial melt that is formed affects the crustal-scale thermal profile. The latent heat of fusion term causes cooling, the magnitude of which is dependent on the amount of partial melt that is formed. For the high-emplacement rate scenario (Figure 5b), the difference between $~ 5 \%$ vs. 25\% melt present (fluid-absent vs. finite fluid-present F-T curves) in the crustal column leads to an average cooling of $\sim 15^{\circ} \mathrm{C}$.

\subsection{Sill-Scale Thermal Evolution}

To evaluate the thermal evolution of the basaltic sills and adjacent wall rocks at high spatial (1-50 m) and temporal (10-100's of years) resolution, simulations were run using the same sill-emplacement history shown in Figure $2 \mathrm{~b}$ and each of the melt fraction-temperature (F-T) curve cases introduced in section 3.3 (Figure 1). The objective was to evaluate changes in the temperature and melt fraction of the adjacent wall rock within $50 \mathrm{~m}$ of the basaltic sill margin and during the first few hundred years after the sill is emplaced. In all simulations, the emplacement rate is $50 \mathrm{~m} / 10 \mathrm{kyr}$. The following key factors were varied: (1) ambient temperature of the wall rock immediately prior to each sill emplacement, which increases on average as the simulation progresses (Supplementary Information; Figure S7), (2) wall rock lithology (granitoid vs. solidified mafic sill), which becomes increasingly variable due to the random emplacement scheme

This article is protected by copyright. All rights reserved. 
(Figure 6), (3) fluid-absent vs. finite fluid-present F-T curves, (4) sill thickness, and (5) the distribution of latent heat in basaltic sills across the liquidus-solidus interval.

\subsubsection{Temperature changes within 100's of yrs of sill emplacement}

\subsubsection{Heating of adjacent 50 m of wall rock}

After each 50-m basalt sill is emplaced, the ambient temperature of the crustal column steadily increases (Figure 2). Therefore, the temperature of the adjacent wall rock at the time of each sill emplacement varies with time (and location within the crustal column). In Figures 7 and 8, four different cases of temperature vs. time for the newly emplaced sill and the adjacent $50 \mathrm{~m}$ of wall rock above the sill are shown (see Supplementary Information, Figures S8-S9, for temperature vs. time plots at 0.3 GPa). Ambient temperature refers to the temperature of the wall rock immediately prior to sill emplacement. Each column of sub-figures in Figure 7 refers to a different wall-rock lithology (Figure 6), which becomes more variable as sill emplacement progresses. The two rows in Figures 7 and 8 compare fluid-absent and finite fluid-present F-T curves (Figure 1) for the adjacent wall rock. The ambient temperature at the time each basaltic sill was emplaced is also noted, and there is some minor variation between fluid-absent and finite fluid-present scenarios.

In all cases (Figure 7), within the first 50 years of sill emplacement, there is an abrupt jump in temperature within the adjacent wall rock. When the ambient temperature 
is $\sim 420^{\circ} \mathrm{C}$, temperatures reach $\geq 700^{\circ} \mathrm{C}$ for 50 yrs within $15 \mathrm{~m}$ of adjacent wall rock. When the ambient temperature is $\sim 516^{\circ} \mathrm{C}$, temperatures are $\geq 700^{\circ} \mathrm{C}$ for $150 \mathrm{yrs}$ within 20 $\mathrm{m}$ of adjacent wall rock. When the ambient temperature is $\sim 611^{\circ} \mathrm{C}$, temperatures reach $\geq 700^{\circ} \mathrm{C}$ for 500 years (and are $\geq 680^{\circ} \mathrm{C}$ for 900 years) within $50 \mathrm{~m}$ of the sill margin. When the ambient temperature is $\sim 657^{\circ} \mathrm{C}$ (Figure 8), temperatures are $\geq 700^{\circ} \mathrm{C}$ for $>1500$ years (and are $\geq 680^{\circ} \mathrm{C}$ for $3 \mathrm{kyr}$ ) within $50 \mathrm{~m}$ of the adjacent wall rock.

Not surprisingly, the most important control on how high temperatures are reached in the wall rock adjacent to a newly emplaced sill, and for how long, is the ambient temperature. The effect of different wall rock lithologies on the thermal profile is minimal. The temperature profiles are slightly cooler when finite fluid-present vs. fluidabsent F-T curves are employed, owing to the effect of latent heat of fusion during partial melting of wall rock (see section 4.1.7).

\subsubsection{Cooling of basaltic sills}

As ambient temperatures increase at the time of sill emplacement, the time it takes for a basaltic sill to cool to its solidus $\left(\sim 680^{\circ} \mathrm{C}\right.$ at $0.5 \mathrm{GPa}$; Figure 1a) also increases (Figure 7). When the ambient temperature is $\sim 420$ vs. $516^{\circ} \mathrm{C}$, the basaltic sill center cools to $680^{\circ} \mathrm{C}$ within $\sim 150$ vs. $\sim 300$ years. When the ambient temperature is $\sim 611$ vs. $657^{\circ} \mathrm{C}$ (Figure 7 and 8), it takes more than 900 vs. 1500 years for the sill center to reach its solidus respectively.

This article is protected by copyright. All rights reserved. 


\subsubsection{Melt fraction changes within 100’s yrs of sill emplacement}

\subsubsection{Adjacent $50 \mathrm{~m}$ of wall rock}

Melt fractions are calculated during each simulation alongside temperature, based on the various F-T curve relationships (Figure 1), within each wall rock lithology (granitoid vs. mafic sill). The amount of water that is present (i.e., fluid-absent vs. finite fluid-present conditions) plays a primary role in the extent of wall rock partial melting. Plots of melt fraction vs. time since sill emplacement are shown in Figures 9 and 10 (see Supplementary Information, Figures S10-S11, for melt fraction vs. time plots at 0.3 GPa). Each column of sub-figures in Figures 9 and 10 refers to a different ambient temperature and wall-rock lithology (Figure 6), whereas the two rows compare fluid-absent and finite fluid-present F-T curves for the adjacent wall rock (Figure 1).

In all cases (Figure 9 and 10), within the first 50 years of sill emplacement, there is an abrupt jump in melt fraction within the adjacent wall rock. For the case of the $25^{\text {th }}$ sill emplacement, the ambient temperature is $\sim 420^{\circ} \mathrm{C}$ and the adjacent $50 \mathrm{~m}$ of wall rock is all granitoid. In this case, the degree of melting in the adjacent wall rock $(\leq 20 \%$ and $\leq 40 \%$, respectively) is most strongly controlled by fluid-absent vs. finite fluid-present conditions (Figure 9a and 9d). In the case of the $50^{\text {th }}$ versus $72^{\text {nd }}$ sill emplacements, an additional control on the degree of melting is the lithology of the wall rock adjacent to each newly emplaced sill. For example, owing to the random emplacement of basaltic

This article is protected by copyright. All rights reserved. 
sills, by chance the wall rock immediately above the $50^{\text {th }}$ sill is predominantly mafic sill, with a small lens of granitoid 4-11 m above the sill margin, whereas the wall rock above the $72^{\text {nd }}$ sill is mafic sill from 0-29 $\mathrm{m}$ and then granitoid (Figure 6). The higher melt fractions when the ambient temperature is lower (i.e., 516 vs. $611^{\circ} \mathrm{C}$ ) are due to the presence of granitoid within $10 \mathrm{~m}$ of the $50^{\text {th }}$ sill's margin, and its absence within the first

$29 \mathrm{~m}$ of the $72^{\text {nd }}$ sill. As expected, melt fractions are higher for finite fluid-present $(\leq 40 \%$ melt) vs. fluid-absent ( $\leq 18 \%$ melt) conditions in all cases.

In Figure 10, the melt fractions in the $50 \mathrm{~m}$ above the $100^{\text {th }}$ sill, where the ambient temperature at the time of sill emplacement was $\sim 657^{\circ} \mathrm{C}$, are shown for fluid-absent versus finite fluid-present conditions. In this case, the wall rock immediately above the sill is granitoid (0-19 m) and then solidified mafic sill (Figure 6). Under finite fluidpresent conditions, the granitoid reaches $45-60 \%$ melt fraction and remains above 30\% melt fraction for $\sim 400$ years, whereas the mafic sill reaches $\leq 12 \%$ melt and remains above 5\% melt for $\sim 400$ years. The temperature and melt fraction profile through the wall rock 50-m column is summarized in Figure 6 for various sill emplacements (at the point in time when the basaltic sill center has reached $80 \%$ crystallization).

\subsubsection{Crystallization of basaltic sills}

As ambient temperatures increase at the time of sill emplacement, the time it takes for the center of the basaltic sills to crystallize to $20 \%$ melt fraction also increases 
(Supplementary Information; Figure S7). It is at this stage of crystallization that the exsolution (and loss) of an $\mathrm{H}_{2} \mathrm{O}$-rich fluid phase from the basaltic sill begins, as discussed below. When the ambient temperature is 420 vs. $516^{\circ} \mathrm{C}$, the basaltic sill center is $80 \%$ crystallized within $\sim 50$ vs. $\sim 69$ years. When the ambient temperature is 611 and $657^{\circ} \mathrm{C}$ (Figure 9 and 10), it takes $\sim 101$ and $~ 128$ years, respectively, for the sill center to reach $80 \%$ crystallization.

\subsubsection{Effect of variable thickness of basaltic sills}

There are two causes for why varying the thickness of newly-emplaced basaltic sills (e.g., 10, 50 and $100 \mathrm{~m}$ ) controls the degree of partial melting that develops in the adjacent wall rock for any specified ambient crustal temperature. The first cause is the markedly different crustal lithologies (i.e., distribution of mafic sills within granitoid) that develop, dependent on whether sill thicknesses are $50 \mathrm{~m}$ (Figure 6) or alternatively either 10 or $100 \mathrm{~m}$ (Figure 11). Because mafic sills and granitoid have distinctly different F-T curves, resulting melt fractions will vary. The second reason is that sill thickness strongly controls the temperature evolution in the surrounding wall rock (e.g., Furlong et al., 1991; Annen, 2017). Variations in the thermal profile of the adjacent wall rock at specified ambient crustal temperatures for 10- and 100-m thick sills are shown in Supplementary Information (Figures S12-S15). Of relevance to this study is the impact of varying sill thickness on the extent of partial melting that occurs along wall-rock margins. 
In the case of a $10-\mathrm{m}$ thick sill emplaced into the crust at $\sim 613^{\circ} \mathrm{C}$ (Figure 12f), $<10 \%$ melt fraction will form in granitoid wall rock (finite fluid-present) for $\leq 5$ years within $10 \mathrm{~m}$ of the sill margin. In contrast, under similar conditions (ambient temperature and finite fluid-present) a newly-emplaced 100 -m thick sill causes $\geq 30 \%$ partial melting in granitoid wall rock for $\sim 800$ years up to $30 \mathrm{~m}$ distant from the sill margin (Figure 13f). Moreover, when the ambient temperature is as low as $\sim 431^{\circ} \mathrm{C}$, the emplacement of a 100m thick sill induces significant partial melting $(\geq 20 \%)$ of granitoid (finite fluid-present conditions) for $\leq 300$ years within $20 \mathrm{~m}$ from the sill margin (Figure 13d). Importantly, the results in Figure 12 (10-m sills) and Figure 13 (100-m sills) are both markedly different from those obtained under similar conditions for 50-m thick basaltic sills (Figure 10). (See Supplementary Information, Figure S16 and S17, for melt fraction results for 10 - and $100-\mathrm{m}$ thick sills when ambient temperature is $\sim 650^{\circ} \mathrm{C}$.) The key observation is that variations in the thickness of newly-emplaced sills $(10,50,100 \mathrm{~m})$ lead to significant differences in the degree and duration of wall-rock partial melting.

\subsubsection{Effect of a variable distribution of latent heat across the liquidus-solidus interval}

An additional factor that may affect the cooling history of a basaltic sill and the transient heating of the adjacent wall rock is a non-linear distribution of latent heat across the liquidus-solidus interval. For the cases shown in Figures 7-10, latent heat is distributed linearly. In the two alternative cases (Supplementary Information; Figure S4),

This article is protected by copyright. All rights reserved. 
where (1) $75 \%$ of the latent heat is released in the first $25 \%$ of crystallization and (2) $75 \%$ of the latent heat is released in the last $25 \%$ of crystallization, the time it takes the $100^{\text {th }}$ basaltic sill to cool to $810^{\circ} \mathrm{C}(\sim 80 \%$ crystallization at $0.3 \mathrm{GPa}$; Figure $1 \mathrm{a})$, is $\sim 6$ years longer and $\sim 29$ years shorter, respectively, compared to the $\sim 120$ years it takes for a linear distribution of latent heat (Supplementary Information; Figure S4c). Similarly, the time interval over which the adjacent wall rock, $10 \mathrm{~m}$ from sill margin, remains $\geq 740^{\circ} \mathrm{C}$ ( $\geq 30 \%$ melt fraction; finite fluid-present conditions, Figure 1c), is $\sim 9$ years longer and 37 years shorter, respectively for case 1 and case 2 (Figure S4a).

The most important parameter to track is the difference in time between the duration of wall rock heating (e.g., $10 \mathrm{~m}$ above sill $\geq 740^{\circ} \mathrm{C}$ ) and the time it takes the basaltic sill to crystallize to $80 \%$ (i.e,. to $810^{\circ} \mathrm{C}$; Figure $1 \mathrm{a}$ ), which marks the onset of fluid exsolution (see Section 4.3). For a linear distribution of latent heat, this time interval for the $100^{\text {th }}$ sill (Figure 6) is 275 years, whereas for case 1 and case 2 (Figure S4a), the time interval is 3 years longer and 8 years shorter, respectively. Therefore, a non-linear distribution of latent heat has little effect on the relative time scale between the cooling of a basaltic sill and the transient heating of the adjacent wall rock.

\subsection{Transfer of water from basaltic sills to partial melt of adjacent wall rock}

A final process we explore is the transfer of dissolved water from the basaltic sills into partial melts of the adjacent wall rock, and what conditions are required for this to 
occur. For example, the solubility limit for dissolved water in the melt is $\sim 10 \mathrm{wt} \%$ in a basalt that is emplaced at a depth with an ambient pressure of 0.5 GPa (e.g., Behrens et al., 2001; Zhang et al., 2007). If the initial water content is 3 wt\% (Gazel et al., 2012), $10 \mathrm{wt} \% \mathrm{H}_{2} \mathrm{O}$ will be reached in the melt during late-stage crystallization. Therefore, exsolution of an $\mathrm{H}_{2} \mathrm{O}$-rich fluid phase is expected to occur by the time the sill center reaches $80 \%$ crystallization. Based on results from Bachmann and Bergantz (2006), migration of an exsolved fluid phase (via “gas sparging”) through partially molten sill and wall rock is expected, and transport distances of 5-10 m are plausible in 5-40 years. The question is whether the time duration for partial melting in the adjacent wall rock (e.g. Figure 14) matches the time scale required for the basaltic sill to crystallize $~ 80 \%$, enabling transfer of a fluid phase to the adjacent wall rock.

In Figure 14a and b, the time it takes (relative to the instant of sill emplacement) for granitoid wall rock at specified distances $(1,5,10,20,30$, and $50 \mathrm{~m})$ above the sill margin to reach a certain temperature, and thus melt fraction (finite fluid-present conditions), is shown. Superimposed on these plots are isopleths of melt fraction (10 and 20\%) at each depth, based only upon the sill emplacements where all of the material up to that depth was granitoid. The valley shaped pattern for an isopleth of melt fraction in the wall rock, at a given distance from the sill margin, illustrates the initial, transient heating of the wall rock (i.e., at a given location relative to the sill margin, the $10 \%$ melt fraction moves downward as a function of ambient temperature), followed by the subsequent 
cooling of the wall rock (at a given location relative to the sill margin, the $10 \%$ melt fraction moves upward as a function of ambient temperature). Pairs of same-colored points at the same ambient temperature denote the times after a given sill emplacement in which the wall rock partially melts above or solidifies below a certain melt fraction, where dot color corresponds to the distance from the sill margin. Spacing between those pairs of points is the time interval in which the wall rock at that distance from the sill has melt fraction above the indicated level. Also shown in this plot is a solid red curve that marks the time at which the center of a recently emplaced basaltic sill reaches $80 \%$ crystallization (Figure S7b), and therefore exsolution of an $\mathrm{H}_{2} \mathrm{O}$-rich fluid phase. Tie lines located to the right of this curve mark the time interval where fluid-present conditions in granitoid wall rock are most likely to exist, owing to transfer of an exsolved $\mathrm{H}_{2} \mathrm{O}$-rich fluid. Therefore, the relevant melt fraction curves for both types of wall rock, granitoid and solidified mafic sills, are those for finite fluid-present conditions, which are also used for the melt fractions illustrated in Figure 6.

In Figure 14c and d, a similar pair of plots is shown, but in these two cases, the wall rock is solidified mafic sills and the isopleths are for 5 and $10 \%$ melt fractions (calculated for finite fluid-present conditions; Figure 1c) at each of the depths considered. The isopleths are based only upon the sill emplacements where all of the wall rock up to that depth was solidified mafic sill. The more refractory nature (i.e. lower melt fraction at a given $\mathrm{T}$ and $\mathrm{H}_{2} \mathrm{O}$ content) of the mafic sills relative to granitoid is illustrated in Figure 
14a-d. Melt fractions of 5-10\% do not develop under finite fluid-present conditions until ambient temperatures are $\geq 500^{\circ} \mathrm{C}$ and only within $1-5 \mathrm{~m}$ of the newly emplaced sill margin. In sharp contrast, melt fractions in finite fluid-present granitoid up to $20 \mathrm{~m}$ from the sill margin exceed $20 \%$, for $\sim 20$ years and $10 \%$ for $\sim 100$ years. Despite the relatively refractory nature of the solidified mafic sills, their close spatial proximity to granitoid increases the chance that small degree partial melts from the mafic sills will develop hydraulic connectivity with the larger degree partial melts from the granitoid, leading to interaction and mixing of compositionally distinct partial melts derived from two very different source rocks.

The efficient transfer of $\mathrm{H}_{2} \mathrm{O}$ fluid from a crystallizing sill to the wall rock is more clearly demonstrated when the loss (i.e., advection) of $\mathrm{H}_{2} \mathrm{O}$ fluid, and thus heat, from the hydrous basalt during late-stage crystallization is accounted for. For example, the loss of $\sim 2 \mathrm{wt} \% \mathrm{H}_{2} \mathrm{O}$ fluid, with a heat content of $\sim 3000 \mathrm{~J} / \mathrm{g}$ at $700^{\circ} \mathrm{C}$ and $0.5 \mathrm{GPa}$ (Burnham et al., 1969) out of a basaltic sill (>80\% crystallized; $\mathrm{Cp}=\sim 1.4 \mathrm{~J} / \mathrm{g}-\mathrm{K}$; Table 1 ) will lead to $\sim 43^{\circ} \mathrm{C}$ of cooling. Moreover, the addition of this $\mathrm{H}_{2} \mathrm{O}$ fluid into $50 \mathrm{~m}$ of wall rock will similarly induce another $\sim 43^{\circ} \mathrm{C}$ of heating, and thus prolong the duration of the transient wall rock heating.

The conclusion, therefore, is that finite fluid-present F-T curves are relevant for granitoid and mafic sill lithologies in wall rock adjacent to newly emplaced sills. Once the ambient temperature is $\sim 600^{\circ} \mathrm{C}$, significant melt fractions develop that contain

This article is protected by copyright. All rights reserved. 
dissolved $\mathrm{H}_{2} \mathrm{O}$ (Figure 6), but at levels below solubility limits owing to the limited amount of $\mathrm{H}_{2} \mathrm{O}$ available from the basaltic sill. The formation of hydrous partial melts that are fluid undersaturated has implications for their rapid segregation and transport as discussed below.

\subsubsection{The role of variable sill thickness}

Figure 15 presents a similar set of plots as shown in Figure 14, but in this case the effect of varying sill thickness $(10,50$ and $100 \mathrm{~m})$ is featured. The comparative results clearly illustrate that partial melting along the wall-rock margins of newly-emplaced sills is far more extensive for thicker (100-m) versus thinner (10-m) sills. In the case of 10-m thick sills, very limited and transient ( $<20$ years) partial melts form in the wall-rock margin above newly-emplaced sills, even when ambient temperatures are relatively high $\left(\geq 600{ }^{\circ} \mathrm{C}\right)$. In contrast, in the case of 100 -m thick sills, extensive ( $\left.>20 \%\right)$ and long-lived (>300 years) melt fractions develop along a new sill margin, even when ambient temperatures are relatively low $\left(\sim 400^{\circ} \mathrm{C}\right)$. These results underscore the role of variable sill thickness is controlling the extent and duration of partial melting along the wall-rock margins of a newly-emplaced sill, as well as the ambient temperature at which significant wall-rock partial melting can occur.

\section{Discussion}

This article is protected by copyright. All rights reserved. 


\subsection{Development of crustal-scale thermal profiles and mixed lithologies}

Several factors influence, to varying degrees, the temperature-depth profile through the crustal column due to the influx of basaltic sills. Among the parameters explored in this study, three exert the strongest control: (1) random vs. fixed emplacement of sills, (2) the initial depth range of sill emplacement, and (3) the time interval over which a thickness of basalt is emplaced. These results are broadly consistent with previous work in the literature (e.g., Dufek and Bergantz, 2005; Annen et al., 2006; Leeman et al., 2008; Karakas and Dufek, 2015; Colón et al., 2018). An important factor additionally explored in this study is the development of a mixed crustal lithology as the crust is gradually heated through the periodic and random emplacement of basaltic sills. Once temperatures reach values that facilitate partial melting of wall rock, both the original granitoid as well as previously solidified mafic sills are eligible source rocks, leading to two sets of compositionally-distinct partial melts. Therefore, tracking the development of the mixed crustal lithology is as important as tracing the evolving thermal profile through the crust.

The results from this study show that crustal temperatures in the middle-upper crust can reach $>600^{\circ} \mathrm{C}$ with varying proportions of mafic sills embedded within the granitoid crust, dependent on the rate of basalt emplacement, as well as the depth interval over which basalts are initially emplaced. For example, the higher the rate of emplacement, the less basalt is required to heat the crust to $>600^{\circ} \mathrm{C}$ (Figure $4 \mathrm{~b}$ ) and thus 
the lower the ratio of solidified mafic sills to granitoid in the crustal column. Similarly, the deeper and broader the initial depth interval of basalt emplacement, a lower basalt:granitoid ratio is required to heat the crust $>600^{\circ} \mathrm{C}$ (Figure S6).

\subsection{Importance of hydrous partial melts of wall rock and their transport}

An additional factor of potential relevance to crustal-scale thermal profiles is the formation, and then advection, of partial melts along the wall-rock margins of newly emplaced sills. The high spatial and temporal resolution of our numerical model reveals the thermal consequences in adjacent wall rock in response to subsequent injections of 50-m thick basaltic sills once ambient crustal temperatures reach $\sim 600^{\circ} \mathrm{C}$. After a new sill is emplaced, temperatures in the adjacent wall rock will reach $\geq 700^{\circ} \mathrm{C}$ for $\geq 500$ years within $50 \mathrm{~m}$ of the sill margin. It is further shown that basaltic sills with an initial $\mathrm{H}_{2} \mathrm{O}$ content of $3 \mathrm{wt} \%$ will undergo $80 \%$ crystallization at the sill center within 100 years when the ambient temperature of the surrounding crust is $\sim 600^{\circ} \mathrm{C}$. After this much crystallization, the basaltic sill is expected to exsolve an $\mathrm{H}_{2} \mathrm{O}$-rich fluid phase, leading to finite fluid-present conditions for the adjacent wall rock at its solidus. Resulting melt fractions in granitoid and mafic-sill wall rock will reach $\geq 20 \%$ and $\geq 5 \%$, respectively, within 30 and $20 \mathrm{~m}$ of the sill margin for $\sim 300$ and $\sim 150$ years, respectively. Given the close spatial association of mafic sills and granitoid in the crustal column (Figure 6), it is

This article is protected by copyright. All rights reserved. 
expected that the relatively low-degree ( $\sim 5 \%)$ partial melts from the mafic sills will interact with relatively high-degree ( 20\%) partial melts from the granitoid wall rock.

Once ambient crustal temperatures reach $\sim 650^{\circ} \mathrm{C}$, any subsequent emplacement of a $50 \mathrm{~m}$ sill will induce substantial partial melting of the adjacent wall rock (Figures 6 and 14). At relatively high melt fractions, the partial melts will be hydrous, but are expected to be fluid undersaturated owing to the limited amount of water available from the basaltic sills. Under these conditions, a large volume increase is created during partial melting. At $500 \mathrm{MPa}$, any dissolved water content less than $10 \mathrm{wt} \%$ will be fluid undersaturated, and the density of a minimum/eutectic melt partial melt from a granitoid (with $\sim 5-9$ wt\% dissolved $\mathrm{H}_{2} \mathrm{O}$ ) will range from $\sim 2360-2290 \mathrm{~kg} / \mathrm{m}^{3}$ (Lange, 1997; Ochs and Lange, 1999), which represents a volume increase of 11-14\%. Experimental studies confirm that partial melting reactions of crustal rocks that produce a positive change in volume lead to micro-cracking and melt-filled fractures (e.g., Connolly et al., 1997; Rushmer, 2001). The formation of near-vertical melt-filled fractures in granitoid wall rock will be further facilitated by the pre-existence of scattered aplite dikes (Lange, 2019), which are ubiquitous in the Sierra Nevada batholith. The near-eutectic bulk composition (high-SiO 2 rhyolite) of aplite dikes ensures extensive melting (limited only by the finite amount of $\mathrm{H}_{2} \mathrm{O}$ present), and they are likely sites for melt-filled fractures to readily develop.

This article is protected by copyright. All rights reserved. 
The rapid development of melt-filled fractures (through melting of aplite dikes) will facilitate the extraction of partial melt from the wall rock (e.g., Sleep, 1988). Once the melt-filled fractures exceed the critical length of a self-propagating dike, it is possible for segregation to occur through dike transport. The critical length at which a vertically oriented dike of constant volume can "self-propagate" is given by the relation, $\left.\mathrm{K}_{\mathrm{c}} /(\Delta \rho \mathrm{g})\right]^{2 / 3}$, where $\mathrm{K}_{\mathrm{c}}$ is the fracture toughness ( 1 MPa $\mathrm{m}^{1 / 2}$; Gonnermann and Taisne, 2015). For a $\Delta \rho$ (rock-melt) of $\sim 290-360 \mathrm{~kg} / \mathrm{m}^{3}$, critical lengths of $\sim 43-50 \mathrm{~m}$ are obtained, which are on the same length scale of the partially melted wall-rock margins. If these partial melts segregate under fluid under-saturated conditions, their liquidus temperatures will decrease during ascent (owing to the positive $\mathrm{dT} / \mathrm{dP}$ slope of their liquidus), which will prolong their transit through the crust despite conductive loss of heat (Waters and Lange, 2017).

The key point for this study is that rapid segregation and transport of these partial melts out of the wall rock is a viable hypothesis that merits further examination, because it will have major consequences to thermal profiles through the crust. The removal of these partial melts by advection will cool their source regions, and heat shallower levels of the crust where they are emplaced. Moreover, this process of melt advection will also alter the composition of the middle-upper crust.

\subsection{Compositional re-working of crust due to transport of wall-rock partial melts}

This article is protected by copyright. All rights reserved. 
Over time, the episodic vertical transport of small volumes of rhyolitic melt (i.e., partial melts of wall rock) into higher levels of the crust will gradually lead to a relatively large accumulation of Plio-Quaternary leucogranite in the upper crust, with a composition that is more evolved than the Mesozoic granodiorite that characterizes most of the exposed granitoid in this region (e.g., Oliver et al., 1993). The rhyolitic partial melts that form along the margins of newly-emplaced basalt sills will be derived from both previously solidified mafic sills and granitoid. Therefore, the two sets of partial melts will be characterized by distinctly different major- and trace-element concentrations, and these two distinctly different partial melts are likely to interact during their segregation and transport, given the close spatial proximity of solidified mafic sills within granitoid wall rock (Figure 6). It is therefore likely that Plio-Quaternary leucogranite bodies of rhyolitic composition (73-75 wt $\% \mathrm{SiO}_{2}$ ) will form in the upper crust with major-element compositions dominated by the more voluminous partial melts of granitoid, but with concentrations of select trace elements (e.g., Sr) that are predominantly derived from the Sr-rich mafic sills (Cousens, 1996). Subsequent partial melting of these leucogranite bodies will lead to high-SiO 2 (76-77 wt\%) rhyolites with relatively low $\mathrm{Sr}$ concentrations, but Sr-isotopic values that mirror those of the associated Long Valley basalts (Lange, 2013), which is a key feature of the Long Valley rhyolites (e.g., Metz and Mahood, 1991; Hildreth and Wilson, 2007; Halliday et al., 1984; Davies et al., 1994). 


\section{Conclusions and Future Work}

There are three broad sets of conclusions that can be drawn from this study regarding the thermal evolution of the crust beneath the Long Valley caldera in eastern California, in response to the emplacement of basaltic magma. First, on the scale of tens of kilometers, as the crustal column gradually heats up due to the random emplacement of basaltic sills, a mixed crustal lithology (solidified mafic sills as well as granitoid) will develop. Importantly, the amount of basalt required to heat $>10 \mathrm{~km}$ of the crustal column to $\sim 600^{\circ} \mathrm{C}$ varies strongly with basalt emplacement rate and the depth interval of basalt emplacement. Therefore, the proportion of mafic sills to granitoid in the crustal column can vary by more than a factor of two (e.g., $\sim 1: 1$ to $<1: 2$ ), once crustal temperatures reach $\sim 600^{\circ} \mathrm{C}$. The abundance and composition of subsequent partial melts of this mixed crustal lithology, at a given $\mathrm{T}-\mathrm{P}_{\mathrm{H} 2 \mathrm{O}}$ condition, will depend strongly on the ratio of mafic sill to granitoid. Therefore, tracking the development of the mixed crustal lithology is as important as tracing the evolving thermal profile through the crust.

A second major conclusion is that in order to accurately track the thermal evolution of the crust due to the influx of basaltic sills, attention must be paid to the transient heating and partial melting of the wall rock adjacent to newly emplaced sills, which depends on the thickness of the basaltic sills as well as the timescale and mechanism by which water is transferred from them to the adjacent wall rock. This requires numerical modeling at high spatial (1 m) and temporal (10-100’s of years) 
resolution, as shown in Figures 7-10. The time scale for the crystallization of the basaltic sills (hundreds of years or less), resulting in the exsolution of a fluid phase, matches the time interval of transient heating of the wall rock. This indicates an effective transfer of water from the crystallizing sill to the wall rock, therefore finite fluid-present conditions prevail and extensive fluid-undersaturated partial melting of wall rock is expected, even when ambient temperatures are below the water-saturated solidus. Moreover, the wallrock partial melts are expected to be derived from both granitoid and previously solidified mafic sills, and the two sets of compositionally distinct melts are likely to interact during segregation and ascent.

A third conclusion is that some of these wall-rock partial melts may undergo rapid segregation and transport via fractures, owing to large volume increases during partial melting and the development of melt-filled fractures within the adjacent wall rock (owing to melting of pre-existing aplite dikes), which exceed the critical length for dike selfpropagation. The advection of these partial melts to higher levels in the crust via fractures will strongly affect the thermal and compositional profile through the middle and upper crust. This is an area of future work and we are currently developing a new numerical 2D model that will include the advection of these partial melts, operating at the same high spatial (1 m) and temporal (1 hour) resolution as the 1-D model presented in this study.

\section{Tables and Figure Captions}

This article is protected by copyright. All rights reserved. 
Table 1. Material Properties

Table 1 References: $\rho$, Holbrook et al. (1992) and Kay et al. (1992); $C p$ and $L$, Bohrson \& Spera (2001); $k$, Chapman \& Furlong (1992) and Hofmeister (1999).

Figure 1. Melt fraction vs. temperature (F-T) relationships for mafic sills and granitoid, calculated with rhyolite MELTS (Gualda et al., 2012). (a) Basalt crystallization at 0.3

\begin{tabular}{lcrrrr}
\hline & Symbol & Mantle & Lower Crust & Granitoid & \multicolumn{1}{c}{ Basalt } \\
\hline Density (solid) $\boldsymbol{k g} / \boldsymbol{m}^{\mathbf{3}}$ & $\rho_{S}$ & 3400 & 3050 & 2650 & 3100 \\
Density (melt) $\boldsymbol{k g} / \boldsymbol{m}^{\mathbf{3}}$ & $\rho_{M}$ & & & 2650 & 2830 \\
Specific Heat $\boldsymbol{J} /(\boldsymbol{k g} \cdot \boldsymbol{K})$ & $C p$ & 1131 & 1390 & 1370 & 1480 \\
Latent Heat $\boldsymbol{J} / \boldsymbol{k g}$ & $L$ & 0 & $3.5 \mathrm{E}+05$ & $2.7 \mathrm{E}+05$ & $4.0 \mathrm{E}+05$ \\
Conductivity $\boldsymbol{J} /(\boldsymbol{s} \cdot \boldsymbol{m} \cdot \boldsymbol{K})$ & $k$ & 3.4 & 2.6 & 3 & 2.6 \\
Melt Compaction & & 0 & 0 & 0 & 0.1 \\
\hline
\end{tabular}

GPa (solid) and 0.5 GPa (dashed). (b) Case 1: Fluid-absent granitoid (orange) and mafic sill (blue) melting. (c) Case 2: Finite fluid-present granitoid and mafic sill melting.

Figure 2. Thermal profiles for (a) fixed-depth emplacement at $10 \mathrm{~km}$ depth and (b) random-depth emplacement with an initial depth range of 10-15 km. Emplacement rate is $5 \mathrm{~km} / \mathrm{Myr}$ in both cases (50-m thick sill every $10 \mathrm{kyr}$ ). Profiles are shown after $0.25 \mathrm{Myr}$ (maroon), 0.5 Myr (red), 0.75 Myr (orange), and $1 \mathrm{Myr}$ (yellow). The crustal lithology after 1 Myr for each emplacement scheme is included, where black is basalt sills and the other rock types are defined in legend in Supplementary Figure 3 (Figure S3). The thin black line denotes the initial geothermal gradient. Fluid-absent F-T curves at 0.3 GPa are used for the wall rock (Figure 1b).

This article is protected by copyright. All rights reserved. 
Figure 3. Thermal profiles after $1 \mathrm{Myr}$ of random-depth emplacement (50 m sill every 10 kyr; fluid-absent at $0.3 \mathrm{GPa}$, Figure 3b) for three minimum spatial resolutions, $25 \mathrm{~m}$ (maroon), $5 \mathrm{~m}$ (orange), and $1 \mathrm{~m}$ (yellow). Pale horizontal background blocks mark the sill positions at $1 \mathrm{Myr}$. The most accurate results are for the highest spatial resolution (1 $\mathrm{m})$.

Figure 4. Thermal profiles for different rates of random emplacement: $5 \mathrm{~km}$ over $1 \mathrm{Myr}$ (yellow), 0.5 Myr (orange), and 0.1 Myr (maroon). (a) Thermal profile over 0-50 km depth with initial and final emplacement ranges marked in yellow. (b) Zoomed-in thermal profile (9-21 km depth). Yellow shading denotes all sill positions after $5 \mathrm{~km}$ of basalt have been emplaced. All three simulations use the same sill position history and fluidabsent F-T curves at $0.3 \mathrm{GPa}$ (Figure 3b). At depths above and below the sill emplacement range, the crustal temperatures are colder when emplacement rates are higher, because there is less time for heat from the basalt to diffuse into cooler regions. This is also why the thermal profile is less smooth and more variable over the $10-20 \mathrm{~km}$ depth interval for the shortest time interval tested (100 kyr).

Figure 5. (a) A comparison of thermal profiles for two different emplacement rates: $5 \mathrm{~km}$ in $1 \mathrm{Myr}$ (red/yellow) and 0.5 Myr (blues) for fluid-absent (light blue/yellow) and fluidpresent conditions (dark blue/red). The results show the higher temperatures that result at higher emplacement rates, and that fluid-absent vs. fluid-present F-T curves (0.3 GPa, Figure 3) exert an influence. (b) Melt fraction profiles for the thermal profiles shown in (a). When melt fractions are low, there is little effect on thermal profiles. When melt fractions are high (dark blue vs. light blue), there is marked cooling ( $\leq 20$ degrees) of the 
thermal profile due to the effect of latent heat of melting for different melt fractions ( $\leq 5$ vs. $25 \%$ ). See text for more details.

Figure 6. Examples of resultant lithologic column 0-50 m above newly emplaced basaltic sills at different stages of random-depth basalt emplacement (50 m sills every $10 \mathrm{kyr}$ ) for initial depth interval 10-15 km. Color-coded bars denote distance above sill margin (similar to those in Figures 7-10). Black is newly emplaced basalt, and gray is old mafic sill. Bolded temperature above each column marks the ambient crustal temperature at the time/depth of $X^{\text {th }}$ sill emplacement (shown in adjacent parenthesis). The number at the base of the column marks the time that basalt sill center reaches $80 \%$ crystals, at which point exsolution of $\mathrm{H}_{2} \mathrm{O}$ fluid is underway. Red and blue curves mark the thermal and melt-fraction profiles ( $0.5 \mathrm{GPa}$; Figure 1c) along the first $50 \mathrm{~m}$ of wall rock adjacent to newly emplaced sills at the time indicated at the base of each column.

Figure 7. Temperature vs. time immediately after sill emplacement at the basaltic sill center (gray line), basaltic sill top margin (black line), and depths 1, 5, 10, 15, 20, 30, and $50 \mathrm{~m}$ above the sill margin (colored lines same as in Figure 6). All cases show random emplacement of $50 \mathrm{~m}$ thick sill every $10 \mathrm{kyr}$ into an initial depth range of 10-15 km. (a) the $25^{\text {th }}$ sill, (b) the $50^{\text {th }}$ sill, and the (c) the $72^{\text {nd }}$ sill; all for fluid-absent F-T curves at 0.5 GPa (Figure 1b). (d-f) same as (a-c), except all for finite fluid-present F-T curves at 0.5 GPa (Figure 1c). Bolded temperature with arrow is the ambient temperature of the crust immediately prior to sill emplacement.

Figure 8. (a) Same as Figure 7 (a), but for the $100^{\text {th }}$ sill; fluid-absent F-T curve. (b) Same as Figure 7 (d), but for the $100^{\text {th }}$ sill; finite fluid-present F-T curve at $0.5 \mathrm{GPa}$. Bolded 
temperature with arrow is the ambient temperature of the crust immediately prior to sill emplacement.

Figure 9. Same as Figure 7, but melt fraction instead of temperature is shown versus time immediately after sill emplacement. All symbols and colors are the same as in Figure 7. Arrows (in e-f) point to the different lithology (granitoid vs. mafic sill) of the wall rock (see Figure 6).

Figure 10. Same as Figure 8, but melt fraction instead of temperature is shown versus time immediately after sill emplacement. All symbols and colors are the same as in Figure 7. Arrows (in b) point to the different lithology (granitoid vs. mafic sill) of the wall rock (see Figure 6).

Figure 11. Examples of a resultant lithologic column (a) 0-50 m above newly emplaced 10-m thick basaltic sills (10 m/2 kyr) and (b) 0-100 m above newly emplaced 100-m thick basaltic sills (100 m/20 kyr) at different stages of emplacement. The initial depth interval is $10-15 \mathrm{~km}$ in both cases. Color-coded bars denote distance above sill margin (similar to that in figure 6). Black is newly emplaced basalt, and gray is old mafic sill. Bolded temperature above each column marks the ambient crustal temperature at the time/depth of Xth sill emplacement (shown in adjacent parenthesis). The number at the base of the column marks the time that basalt sill reaches $80 \%$ crystals, at which point exsolution of H2O fluid is underway. Sill scale results for (a) are shown in Figures 12, S12-S13, and S16. Sill scale results for (b) are shown in Figures 13, S14-S15 and S17.

Figure 12. Melt fraction vs. time immediately after 10-m thick sill emplacement at the 
basaltic sill center (gray line), basaltic sill top margin (black line), and depths 1, 5, 10, 15, 20, 30, and $50 \mathrm{~m}$ above the sill margin (colored lines the same as in Figure 11). All cases are random emplacement of 10-m thick sill every 2 kyr into an initial depth range of 10$15 \mathrm{~km}$. (a) the $100^{\text {th }}$ sill, (b) the $275^{\text {th }}$ sill, and (c) the $375^{\text {th }}$ sill from a single simulation realization; all for fluid-absent F-T curves at $0.5 \mathrm{GPa}$ (Figure 1b). (d-f) same as (a-c), except for finite fluid-present F-T curves at $0.5 \mathrm{GPa}$ (Figure 1c). Arrows (in e-f) point to different lithology (granitoid vs. mafic sill) of the wall rock (see Figure 11).

Figure 13. Melt fraction vs. time immediately after 100-m sill emplacement at the basaltic sill center (gray line), basaltic sill top margin (black line), and depths 1, 5, 10, 15, 20, 30, 50, and $100 \mathrm{~m}$ above the sill margin (colored lines the same as in Figure 11). All cases are random emplacement of 100-m thick sill every 20 kyr into an initial depth range of $10-15 \mathrm{~km}$. (a) the $11^{\text {th }}$ sill, (b) the $27^{\text {th }}$ sill, and (c) the $40^{\text {th }}$ sill from a single simulation; all for fluid-absent F-T curves at 0.5 GPa (Figure 1b). (d-f) same as (a-c), except for finite fluid-present F-T curves at 0.5 GPa (Figure 1c). Arrows (in c and f) point to different lithology (granitoid vs. mafic sill) of the wall rock (see Figure 11).

Figure 14. (a) Plot of ambient temperature versus time with superimposed isopleths of fluid-present granodiorite at fixed distances above the basaltic sill margin (color-coded; see legend) that contain $\geq 10 \%$ melt fraction at $0.5 \mathrm{GPa}$. Red line is the time it takes a newly emplaced basaltic sill to crystallize 80\% (onset of fluid exsolution; Figure S7). Bold isothermal lines denote time interval, for a specific initial ambient temperature, over which granitoid wall rock is under finite fluid-present conditions and thus contains $\geq 10 \%$ melt fraction. (b) Same as (a), but for granitoid with $\geq 20 \%$ melt fraction. (c) Same as (a), but for solidified mafic sills with $\geq 10 \%$ melt fraction. (d) Same as (a), but for solidified 
mafic sills with $\geq 5 \%$ melt fraction. Isopleth curves that connect the color-coded dots are hand drawn.

Figure 15. Plots of ambient temperature versus time with superimposed isopleths of finite fluid-present granodiorite (bold) and mafic sill (thin) partial melting windows. (a-c) Results for 10-m thick sills at 10, 20 and 50 m above the sill margin. (d-f) Results for 50m thick sills at 10, 20 and $50 \mathrm{~m}$ above the sill margin. (g-i) Results for 100-m thick sills at 10, 20 and $50 \mathrm{~m}$ above the sill margin.

\section{Acknowledgements}

This research was supported by the National Science Foundation (EAR-1855751), as well as discretionary research funds from the University of Michigan (UM). The first author was partially supported by a graduate student fellowship from the Department of Earth and Environmental Sciences at the UM. The model code, a run file, and representative output can be found at DOI: 10.5281/zenodo.3549797; more output available upon request.

\section{REFERENCE}

Anderson, A.T., Davis, A.M., \& Lu, F. (2000). Evolution of Bishop Tuff rhyolitic magma based on melt and magnetite inclusions and zoned phenocrysts. Journal of Petrology, 41(3), 449-473. https://doi.org/10.1093/petrology/41.3.449

This article is protected by copyright. All rights reserved. 
Andersen, N.L., Jicha, B.R., Singer, B.S., \& Hildreth, W. (2017). Incremental heating of Bishop Tuff sanidine reveals preeruptive radiogenic Ar and rapid remobilization from cold storage. Proceedings of the National Academy of Sciences of the United States of America, 114(47), 12407-12412. https://doi.org/10.1073/pnas.1709581114

Annen, C., Blundy, J.D., \& Sparks, R.S.J. (2006). The genesis of intermediate silicic magmas in deep crustal hot zones. Journal of Petrology, 47(3), 505-539. http://doi.org/10.1093/petrology/egi084

Annen, C. (2017) Factors affecting the thickness of thermal aureoles. Frontiers in Earth Science, 5:82. doi: 10.3389/feart.2017.00082

Bachmann, O., \& Bergantz, G.W. (2006). Gas percolation in upper-crustal silicic crystal mushes as a mechanism for upward heat advection and rejuvenation of nearsolidus magma bodies. Journal of Volcanology and Geothermal Research. 149, 85-102. https://doi.org/10.1016/j.jvolgeores.2005.06.002

Bateman, P.C. (1992) Plutonism in the central part of the Sierra Nevada batholith, California. U.S. Geological Survey Professional Paper, 1483, 1-186.

Bailey, R.A. (1989). Geologic map of the Long Valley caldera, Mono-Inyo craters volcanic chain, and vicinity, eastern California. U.S. Geological Survey Map I1933. https://doi.org/10.3133/i1933

This article is protected by copyright. All rights reserved. 
Behrens, H., Meyer, M., Holtz, F., Benne, D. \& Nowak, M. (2001). The effect of alkali ionic radius, temperature, and pressure on solubility of water in $\mathrm{MAlSi}_{3} \mathrm{O}_{8}$ melts (M=Li, Na, K, Rb). Chemical Geology, 174, 275-289. http://doi.org/10.1016/S0009-2541(00)00320-X

Bindeman, I.N. \& Simakin, A.G. (2014). Rhyolites-hard to produce, but easy to recycle and sequester: Integrating microgeochemical observations and numerical models. Geopshere, 10(5), 930-957. https://doi.org/10.1130/GES00969.1

Bohrson, W. A. \& Spera, F. J. (2001). Energy-constrained open system magmatic processes II: application of energy-constrained assimilation-fractional crystallization (EC-AFC) model to magmatic systems. Journal of Petrology, 42, 1019-1041. https://doi.org/10.1093/petrology/42.5.1019

Burnham, C.W., Holloway JR, Davis, N.F. (1969). Thermodynamic properties of water to $1000^{\circ} \mathrm{C}$ and 10,000 bars. Research and Development Progress Report No. 414, US Department of the Interior. https://doi.org/10.1130/SPE132

Chapman, D. S. \& Furlong, K. P. (1992). Thermal state of the continental lower crust. In, Fountain, D. M., Arculus, R. \& Kay, R. W. (Eds), Continental Lower Crust. Developments in Geotectonics. 23, 179-199.

Christiansen, R.L. (2001). The Quaternary and Pliocene Yellowstone volcanic field of Wyoming, Idaho, and Montana. US Geological Survey Professional Paper, 729 G, G1-G145. https://doi.org/10.3133/pp729G

This article is protected by copyright. All rights reserved. 
Coleman, D.S., Bartley, J.M., Glazner, A.F., \& Pardue, M.J. (2012). Is chemical zonation in plutonic rocks driven by changes in source magma composition or shallowcrustal differentiation? Geosphere, 8(6), p. 1568-1587.

Colón, D.P., Bindeman, I.N. \& Gerya, T.V. (2018). Thermomechanical modeling of the formation of a multilevel, crustal-scale magmatic system by the Yellowstone plume. Geophysical Research Letters, 45, 3873-3879. https://doi.org/10.1029/2018GL077090

Connolly, J.A.D., Holness, M.B., Rubie, D., Rushmer, T. (1997). Reaction-induced microcraking: an experimental investigation of a mechanism for enhancing anatectic melt extraction. Geology, 25, 591-594. http://doi.org/10.1130/00917613(1997)025<0591:RIMAEI >2.3.CO

Cousens, B.L. (1996). Magmatic evolution of Quaternary mafic magmas at Long Valley caldera and the Devils Postpile, California: Effects of crustal contamination on lithospheric mantle-derived magmas. Journal of Geophysical Research, 101(B12), 27673-27689. https://doi.org/10.1029/96JB02093

Davies, G.R., Halliday, A.N., Mahood, G.A. \& Hall, C.M. (1994). Isotopic constraints on the production rates, crystallization histories and residence times of pre-caldera silicic magmas, Long Valley, California. Earth and Planetary Science Letters, 125(4), 17-37. https://doi.org/10.1016/0012-821X(94)90204-6

This article is protected by copyright. All rights reserved. 
Dormand, J., (1996). Numerical Methods for Differential Equations: A Computational Approach, pp. 368, CRC Press LLC, New York.

Du Bray, E.A., John, D.A., Cousens, B.L., Hayden, L.A. \& Vikre, P.G. (2016).

Geochemistry, petrologic evolution, and ore deposits of the Miocene Bodie Hills volcanic field, California and Nevada. American Mineralogist, 101(3), 644-677. https://doi.org/10.2138/am-2016-5440

Dufek, J. \& Bergantz, G.W. (2005). Lower crustal magma genesis and preservation: a stochastic framework for the evaluation of basalt-crust interaction. Journal of Petrology, 46(11), 2167-2195. https://doi.org/10.1093/petrology/egi049

Fliedner, M.M., Klemperer, S.L. \& Christensen, N.I. (2000). Three-dimensional seismic model of the Sierra Nevada arc, California, and its implications for crustal and upper mantle composition. Journal of Geophysical Research, 105(B5), 1089910922. https://doi.org/10.1029/2000JB900029

Flinders, A.F., Shelly, D.R., Dawson, P.B., Hill, D.P., Tripoli, B. \& Shen, Y. (2018). Seismic evidence for significant melt beneath the Long Valley Caldera, California, USA. Geology, 46(9), p. 799-802.

Frassetto, A.M., Zandt, G., Gilbert, H., Owens, T.J. \& Jones, C.H. (2011). Structure of the Sierra Nevada from receiver functions and implications for lithospheric foundering. Geosphere, 7(4), 898-921. https://doi.org/10.1130/GES00570.1

This article is protected by copyright. All rights reserved. 
Furlong, K. P., Hanson, R. B., and Bowers, J. R. (1991). “Modeling thermal regimes,” in Contact Metamorphism, ed D. M. Kerrick (Chelsea, MI: Mineralogical Society of America), 437-498.

Gazel, E., Plank, T., Forsyth, D.W., Bendersky, C., Lee, C.-T., \& Hauri, E.H. (2012).

Lithosphere versus asthenosphere mantle sources at the Big Pine Volcanic Field, California. Geochemistry, Geophysics, Geosystems, 13(1), 1-25. https://doi.org/10.1029/2012GC004060

Gonnermann, H. \& Taisne, B. (2015). Magma transport in dikes. In, Sigurdsson, H. (Ed.), The Encyclopedia of Volcanoes (pp. 215-224)

Gualda, G.A.R., Ghiorso, M.S., Lemons, R.V. \& Carley, T.L. (2012). Rhyolite-MELTS: a modified calibration of MELTS optimized for silica-rich, fluid-bearing magmatic systems. Journal of Petrology, 53(5), 875-890. https://doi.org/10.1093/petrology/egr080

Halliday A.N., Fallick, A.E., Hutchinson, J. \& Hildreth, W. (1984). A Nd, Sr, and O isotopic investigation into the causes of chemical and isotopic zonation in the Bishop Tuff, California. Earth and Planetary Science Letters, 68(3), 379-391. https://doi.org/10.1016/0012-821X(84)90123-7

Hardin, J. O., (2016). Geological analysis of aplite dikes, Texas Canyon Stock, Arizona. Honors Thesis, University of Arizona, August 2016.

This article is protected by copyright. All rights reserved. 
Hetland, E.A., Simons, M. \& Dunham, E.M. (2010). Postseismic and interseismic deformation due to fault creep I: Model description. Geophysical Journal International, 181(1), 81-98. http://dx.doi.org/10.1111/j.1365-246X.2010.04522.x

Hildreth, W. (2004). Volcanological perspectives on Long Valley, Mammoth Mountain, and Mono Craters: several contiguous but discrete systems. Journal of Volcanology and Geothermal Research, 136, 169-198. https://doi.org/10.1016/j.jvolgeores.2004.05.019

Hildreth, W., Fierstein, J., \& Calvert, A. (2017). Early postcaldera rhyolite and structural resurgence at Long Valley Caldera, California. Journal of Volcanology and Geophysical Research, 335, 1-34. https://doi.org/10.1016/j.jvolgeores.2017.01.005

Hildreth, W. \& Wilson, C.J.N. (2007). Compositional zoning of the Bishop Tuff. Journal of Petrology, 48(5), 951-999. https://doi.org/10.1093/petrology/egm007

Hofmeister, A.M. (1999). Mantle values of thermal conductivity and the geotherm from phonon lifetimes. Science, 283, 1699. https://doi.org/10.1126/science.283.5408.1699

Holbrook, W. S., Mooney, W. D. \& Christensen, N. I. (1992). The seismic velocity structure of the deep continental crust. In, Fountain, D. M., Arculus, R. \& Kay, R. W. (Eds), Continental Lower Crust. Amsterdam: Elsevier, pp. 1-43

This article is protected by copyright. All rights reserved. 
Huang, W. \& Russell, R.D. (2011). Adaptive moving mesh methods. Applied mathematical sciences. (Vol. 174). New York, NY: Springer. https://doi.org/10.1007/978-1-4419-7916-2

Huppert, H.E. \& Sparks, R.S.J. (1988). The generation of granitic magmas by intrusion of basalt into continental crust. Journal of Petrology, 29(3), 599-624. https://doi.org/10.1093/petrology/29.3.599

Jackson, M.D., Cheadle, M.J. \& Atherton, M.P. (2003). Quantitative modeling of granitic melt generation and segregation in the continental crust. Journal of Geophysical Research, 108(B7), 2332, https://doi.org/10.1029/2001JB001050

Karakas, O. \& Dufek, J. (2015). Melt evolution and residence in extending crust: Thermal modeling of the crust and crustal magmas. Earth and Planetary Science Letters, 425, 131-144. https://doi.org/10.1016/j.epsl.2015.06.001

Kay, R. W., Kay, S. M \& Arculus, R. J. (1992). Magma genesis and crustal processing. In, Fountain, D. M., Arculus, R. \& Kay, R. W. (Eds), Continental Lower Crust. Amsterdam: Elsevier, pp. 423-445.

Johannes, W. \& Holtz, F (1996). Petrogenesis and Experimental Petrology of Granitic Rocks: Minerals and Rock Series, Volume 22, Berlin, Springer-Verlag, 335 p. https://doi.org/10.1093/petroj/38.1.165

Lange, R.A. (1997). A revised model for the density and thermal expansivity of $\mathrm{K}_{2} \mathrm{O}-$ $\mathrm{Na}_{2} \mathrm{O}-\mathrm{CaOMgO}-\mathrm{Al}_{2} \mathrm{O}_{3}-\mathrm{SiO}_{2}$ liquids from $700-1900 \mathrm{~K}$ : extension to crustal

This article is protected by copyright. All rights reserved. 
magmatic temperatures. Contributions to Mineralogy and Petrology, 130, 1-11. https://doi.org/10.1007/s004100050345

Lange, R.A. (2013). The origin of highly evolved, voluminous rhyolites by progressive, multiple episodes of partial melting: the resolution of several paradoxes. Geochemical Society Ingerson Lecture, Geological Society of America Abstracts with Programs, vol. 45, no. 7, p. 84.

Lange, R.A. (2019). Evidence for rapid transport of rhyolite melt during hydrous partial melting of granitoid: the critical role of pre-existing aplite dikes and fluidundersaturated conditions. American Geophysical Union Fall Meeting Abstracts, V44A-01.

Leeman, W.P., Annen, C. \& Dufek, J. (2008). Snake River Plain - Yellowstone silicic volcanism: implications for magma genesis and magma fluxes. Geological Society, London, Special Publications, 304, 235-259.

https://doi.org/10.1144/SP304.12

Levander, A. \& Miller, M.S. (2012). Evolutionary aspects of lithosphere discontinuity structure in the western U.S. Geochemistry, Geophysics, Geosystems, 13(7), Q0AK07. https://doi.org/10.1029/2012GC004056

Lim, S.H., Hetland, E.A. \& Lange, R.A. (2012). Numerical models of transient partial melting of the lower crust during repeated emplacement of basalt sills and subsequent cooling due to advection of melt out of the lower crust. Abstract

This article is protected by copyright. All rights reserved. 
T31G-2708. Presented at 2012 Fall Meeting, AGU, San Francisco, Calif., 3-7 Dec.

Manley C.R., Glazner, A.F. \& Farmer, G.L. (2000). Timing of volcanism in the Sierra Nevada of California: Evidence for Pliocene delamination of the basaltic root? Geology, 28(9), 811-814. https://doi.org/10.1130/00917613(2000)28<811:TOVITS >2.0.CO;2

McKenzie, D. (1984). The generation and compaction of partially molten rock. Journal of Petrology. 25(3), 713-765. https://doi.org/10.1093/petrology/25.3.713

Metz, J.M. \& Mahood, G.A. (1991). Development of the Long Valley, California, magma chamber recorded in precaldera rhyolite lavas of Glass Mountain. Contributions to Mineralogy and Petrology, 106(3), 379-397. https://doi.org/10.1007/BF00324565

Noda, H., Dunham, E. \& Rice, J., (2009). Earthquake ruptures with thermal weakening and the operation of major faults at low overall stress levels. Journal of Geophysical Research, 114, B07302, https://doi.org/10.1029/2008JB006143

Ochs, F.A. \& Lange, R.A. (1999). The density of hydrous magmatic liquids. Science, 283(5406), 1314-1317. https://10.1126/science.283.5406.1314

Oliver, H.W., Moore, J.G. \& Sikora, R.F. (1993). Internal structure of the Sierra Nevada batholith based on specific gravity and gravity measurements. Geophysical Research Letters, 20(20), 2179-2182. https://doi.org/10.1029/93GL01379

This article is protected by copyright. All rights reserved. 
Petford, N. \& Gallagher, K. (2001). Partial melting of mafic (amphibolitic) lower crust by periodic influx of basaltic magma. Earth and Planetary Science Letters, 193(3-4), 483-499. https://doi.org/10.1016/S0012-821X(01)00481-2

Rubin, A.M. (1995). Propagation of magma-filled cracks. Annual Review of Earth and Planetary Sciences, 23, 287-336. https://doi.org/10.1146/annurev.ea.23.050195.001443

Rubin, A.M. (1998). Dike ascent in partially molten rock. Journal of Geophysical Research, 103, 20901-20919. https://doi.org/10.1029/98JB01349

Rudnick, R.L. \& Gao, S. (2014). Composition of the continental crust. Treatise on Geochemistry, 2 ${ }^{\text {nd }}$, 4, 1-51. https://doi.org/10.1016/B978-0-08-095975-7.00301-6

Rushmer, T. (2001). Volume change during partial melting reactions: implications for melt extraction, melt geochemistry and crustal rheology. Tectonophysics, 342, 389-405. https://doi.org/10.1016/S0040-1951(01)00172-X

Saleeby, J., Ducea, M.\& Clemens-Knott, D. (2003). Production and loss of high-density batholitic root, southern Sierra Nevada, California. Tectonics, 22(6), 1064. https://doi.org/10.1029/2002TC001374

Simakin, A.G. \& Bindeman I.N. (2012). Remelting in caldera and rift environments and the genesis of hot, "recycled" rhyolites. Earth and Planetary Science Letters, 337338, 224-235. https://doi.org/10.1016/j.epsl.2012.04.011

This article is protected by copyright. All rights reserved. 
Simon, J.I., Weis, D., DePaolo, D.J., Renne, P.R., Mundil, R. \& Schmitt, A.K. (2014). Assimilation of preexisting Pleistocene intrusions at Long Valley by periodic magma recharge accelerates rhyolite generation: rethinking the remelting model. Contributions to Mineralogy and Petrology, 167, 955. https://doi.org/10.1007/s00410-013-0955-5

Solano, J.M.S., Jackson, M.D., Sparks, R.S.J. \& Blundy, J. (2014). Evolution of major and trace element composition during melt migration through crystalline mush: Implications for chemical differentiation in the crust. American Journal of Science, 314(5), 895-939. https://doi.org/10.2475/05.2014.01

Spera, F.J., \& Bohrson, W.A. (2018). Rejuvenation of crustal magma mush: A tale of multiply nested processes and timescales. American Journal of Science, 318, 90 140. https://doi.org/10.2475/01.2018.05

Stachnik, J.C. Dueker, K., Schutt, D.L., \& Yuan, H. (2008), Imaging Yellowstone plume - lithosphere interactions from inversion of ballistic and diffusive Rayleigh wave dispersion and crustal thickness data. Geochemistry. Geophysics. Geosystems., 9, Q06004, https://doi.org/10.1029/2008GC001992.

Thurber, C., Zhang, H., Brocher, T. \& Langenheim, V. (2009). Regional threedimensional seismic velocity model of the crust and uppermost mantle of northern California. Journal of Geophysical Research, 114, B01304, https://doi.org/10.1029/2008JB005766

This article is protected by copyright. All rights reserved. 
Wallace, P.J., Anderson, A.T. \& Davis, A.M. (1999). Gradients in $\mathrm{H}_{2} \mathrm{O}, \mathrm{CO}_{2}$, and exsolved gas in a large-volume silicic magma system: Interpreting the record preserved in melt inclusions from the Bishop Tuff. Journal of Geophysical Research, 104(B9), 20097-20122. https://doi.org/10.1029/1999JB900207

Wilson, C.J.N. \& Hildreth, W. (1997). The Bishop Tuff: new insights from eruptive stratigraphy. The Journal of Geology, 105(4), 407-440. https://doi.org/10.1086/515937

Yuan, H., \& Dueker, K. (2010). Crustal structure and thickness along the Yellowstone hot spot track: Evidence for lower crustal outflow from beneath the eastern Snake River Plain. Geochemistry, Geophysics, Geosystems. 11, 3. https://doi.org/10.1029/2009GC002787

Zandt, G., Hersh, G., Owens, T.J., Ducea, M., Saleeby, J. \& Jones, C.H. (2004). Active foundering of a continental arc root beneath the southern Sierra Nevada in California. Nature, 431(7004), 41-46. https://doi.org/10.1038/nature02847

Zhang, Y., Xu, Z., Zhu, M. \& Wang, H. (2007). Silicate melt properties and volcanic eruptions. Review of Geophysics, 45(4), RG4004, https://doi.org/10.1029/2006RG000216

This article is protected by copyright. All rights reserved. 

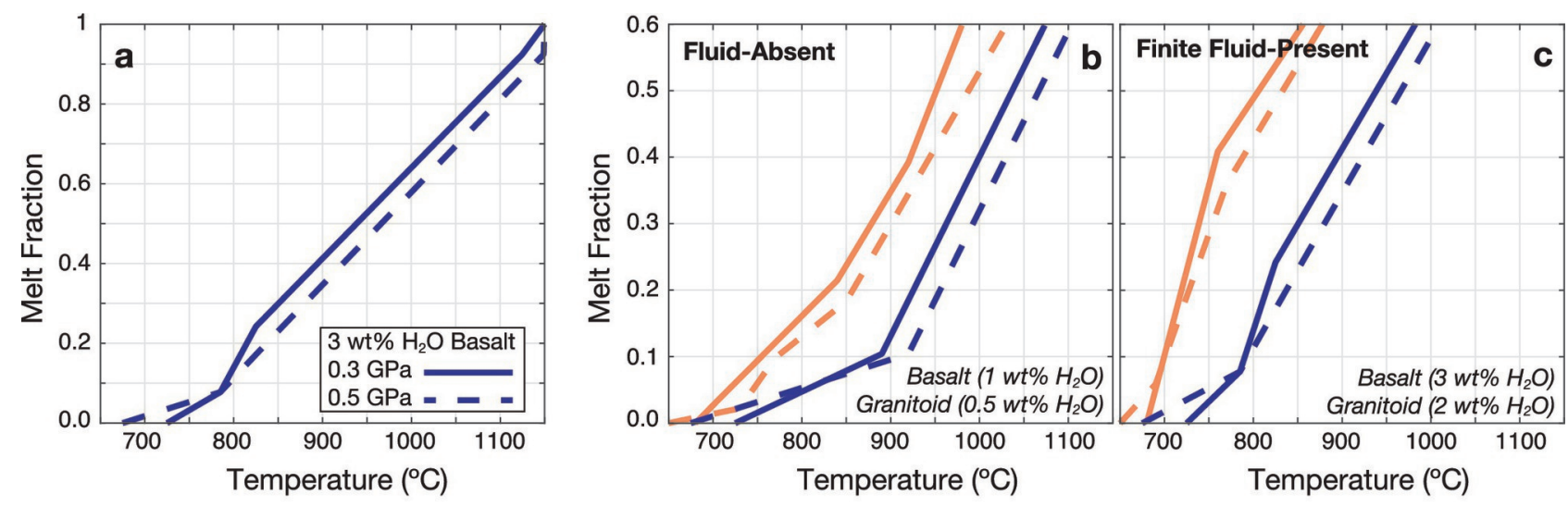

Basalt $=0.3 \mathrm{GPa}$

Granitoid $=-0.3 \mathrm{GPa}$

2018jb016773-f01-z-.eps

This article is protected by copyright. All rights reserved. 


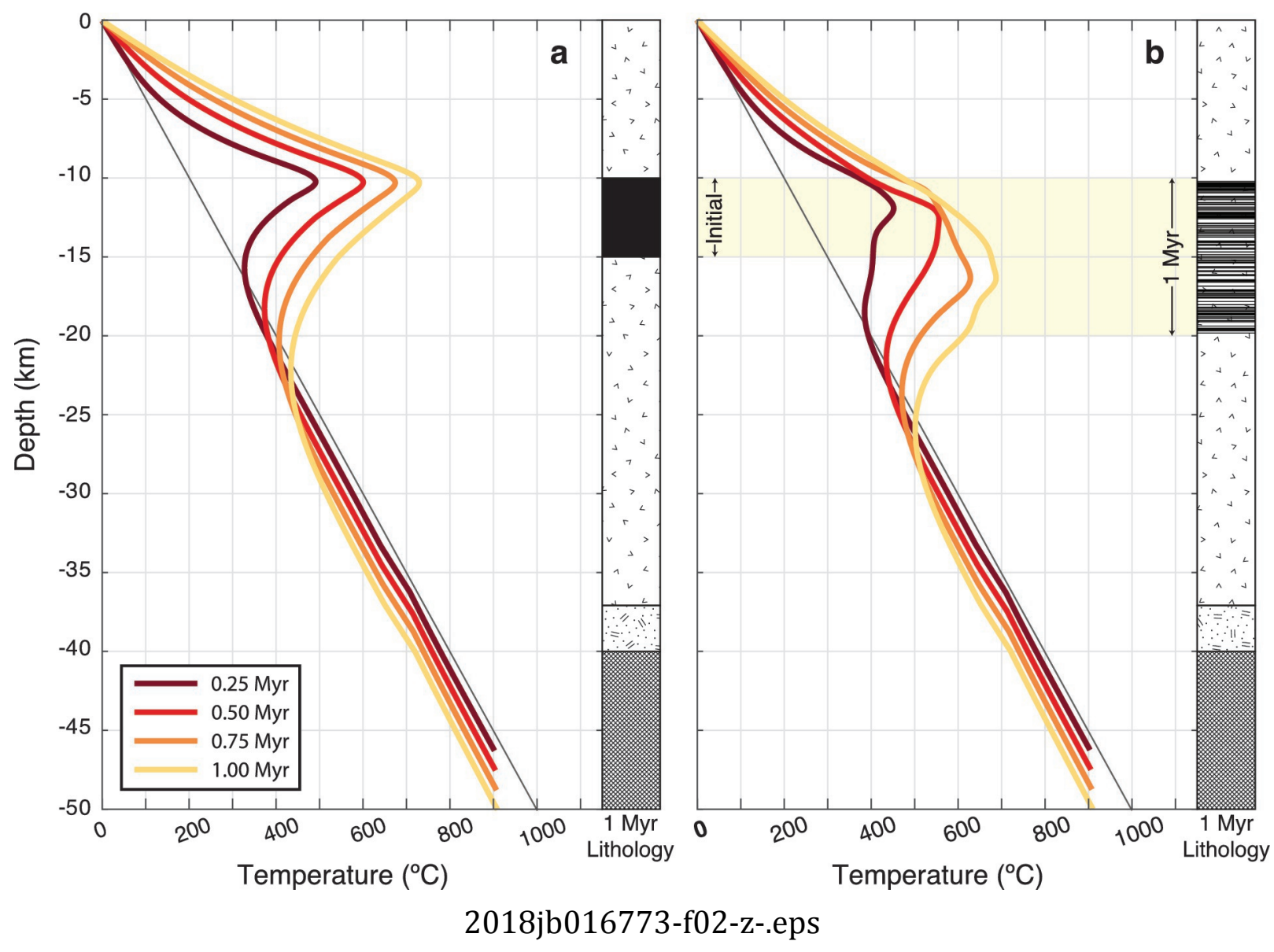

This article is protected by copyright. All rights reserved. 


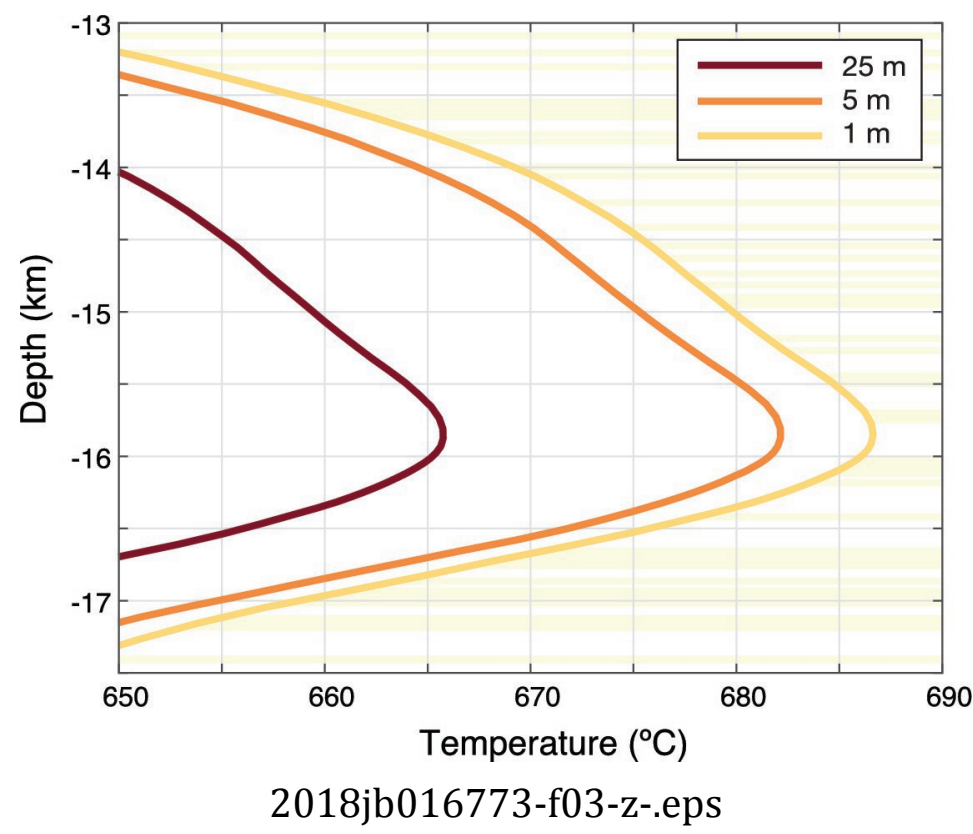

This article is protected by copyright. All rights reserved. 


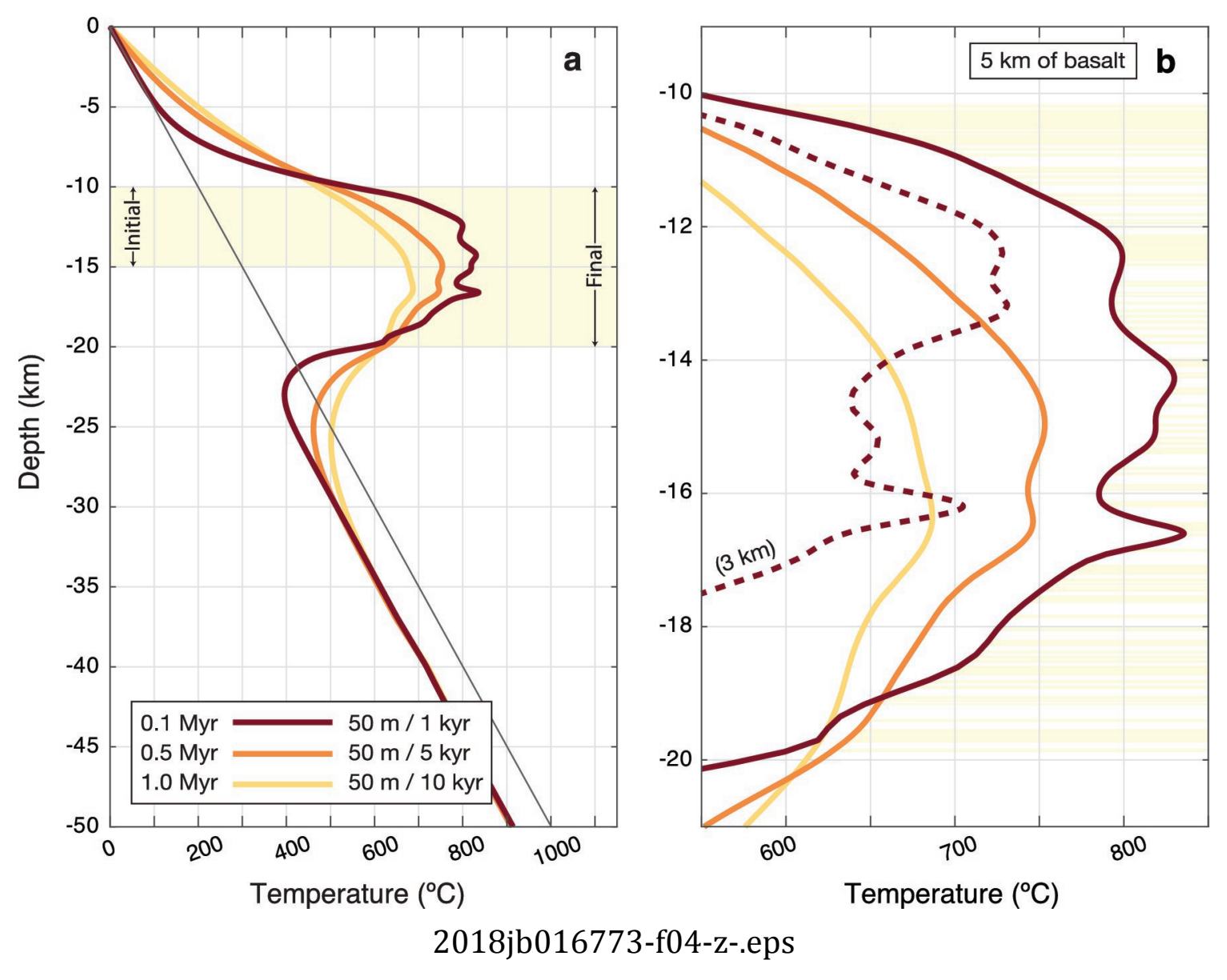

This article is protected by copyright. All rights reserved. 

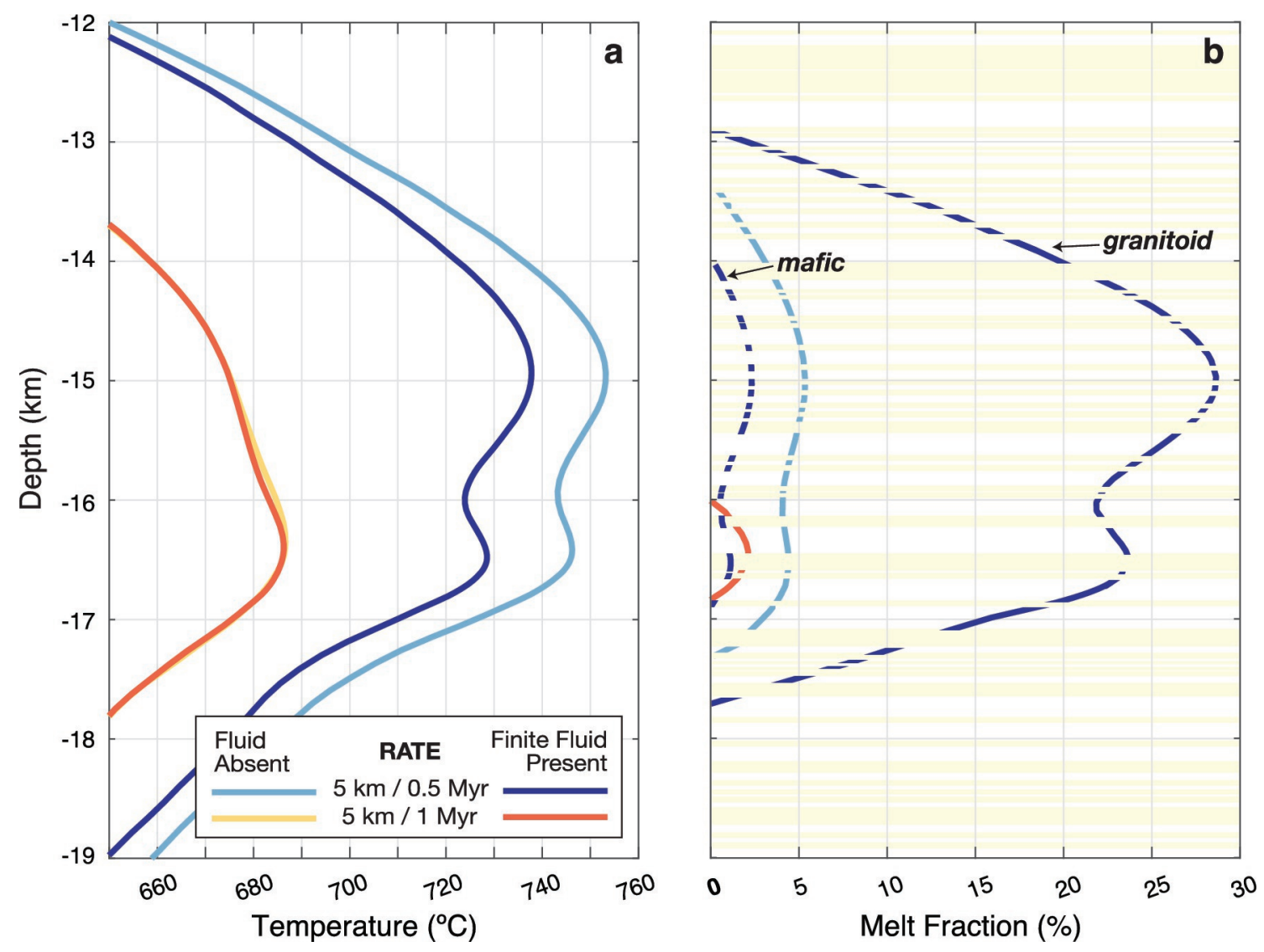

2018jb016773-f05-z-.eps

This article is protected by copyright. All rights reserved. 


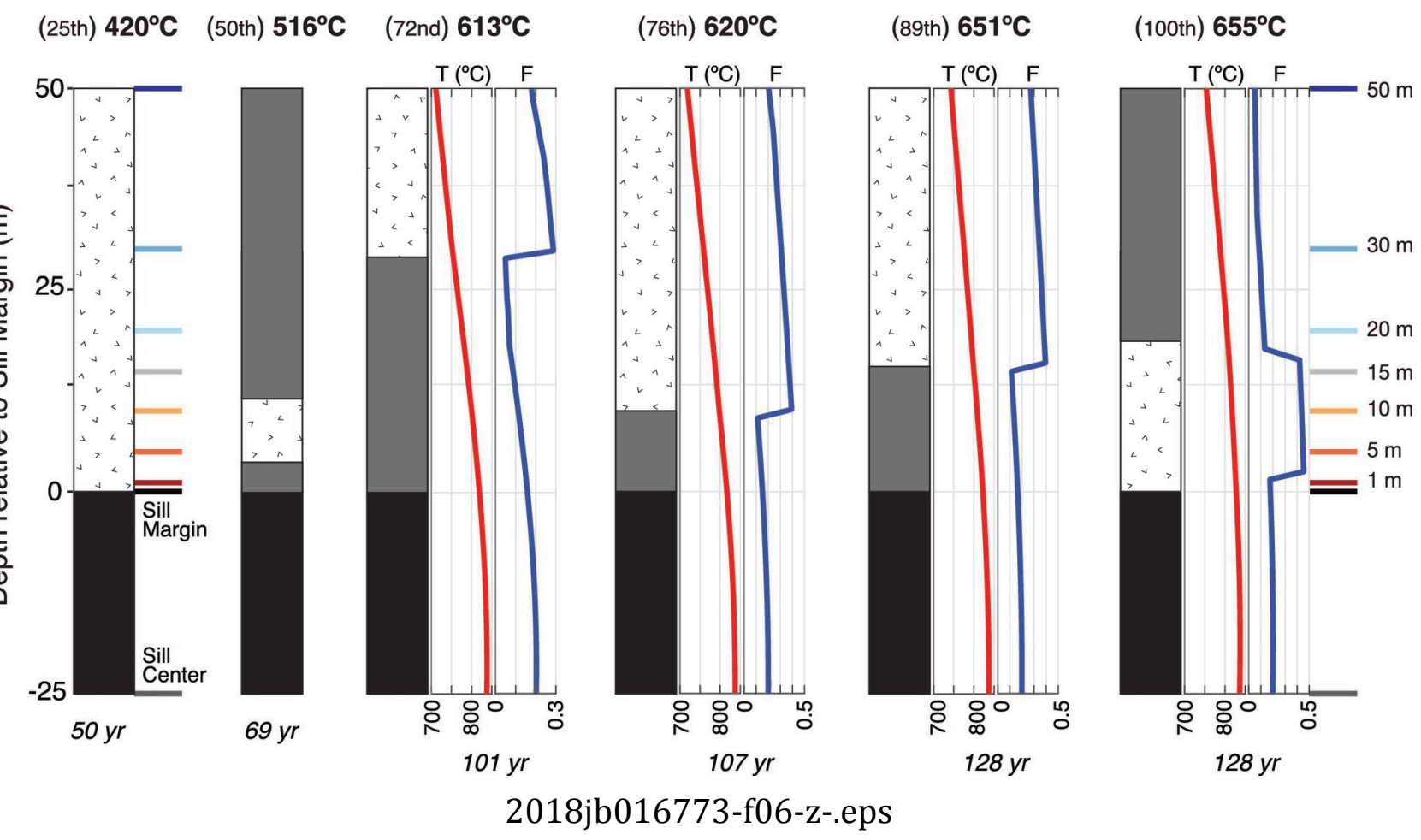

This article is protected by copyright. All rights reserved. 

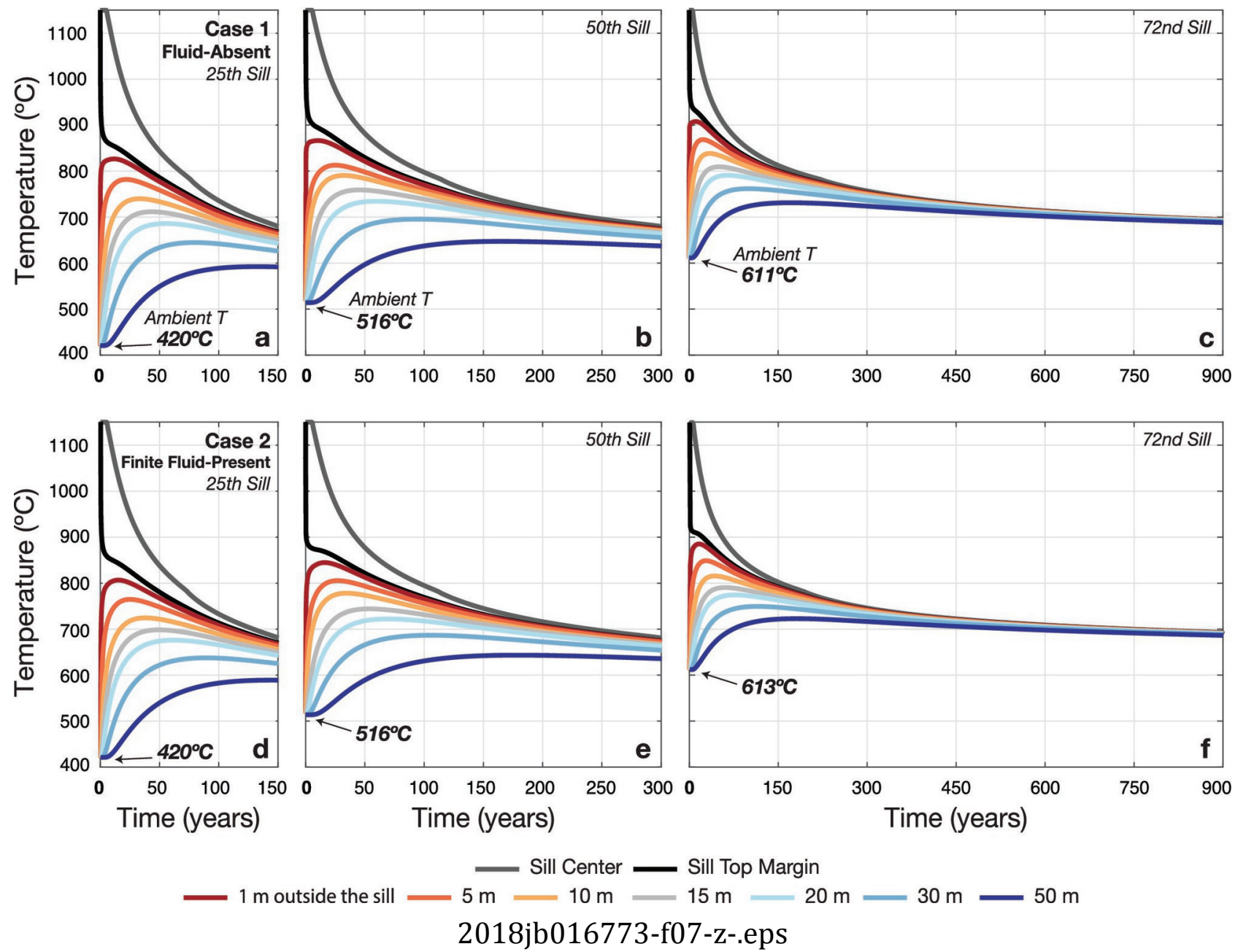

This article is protected by copyright. All rights reserved. 

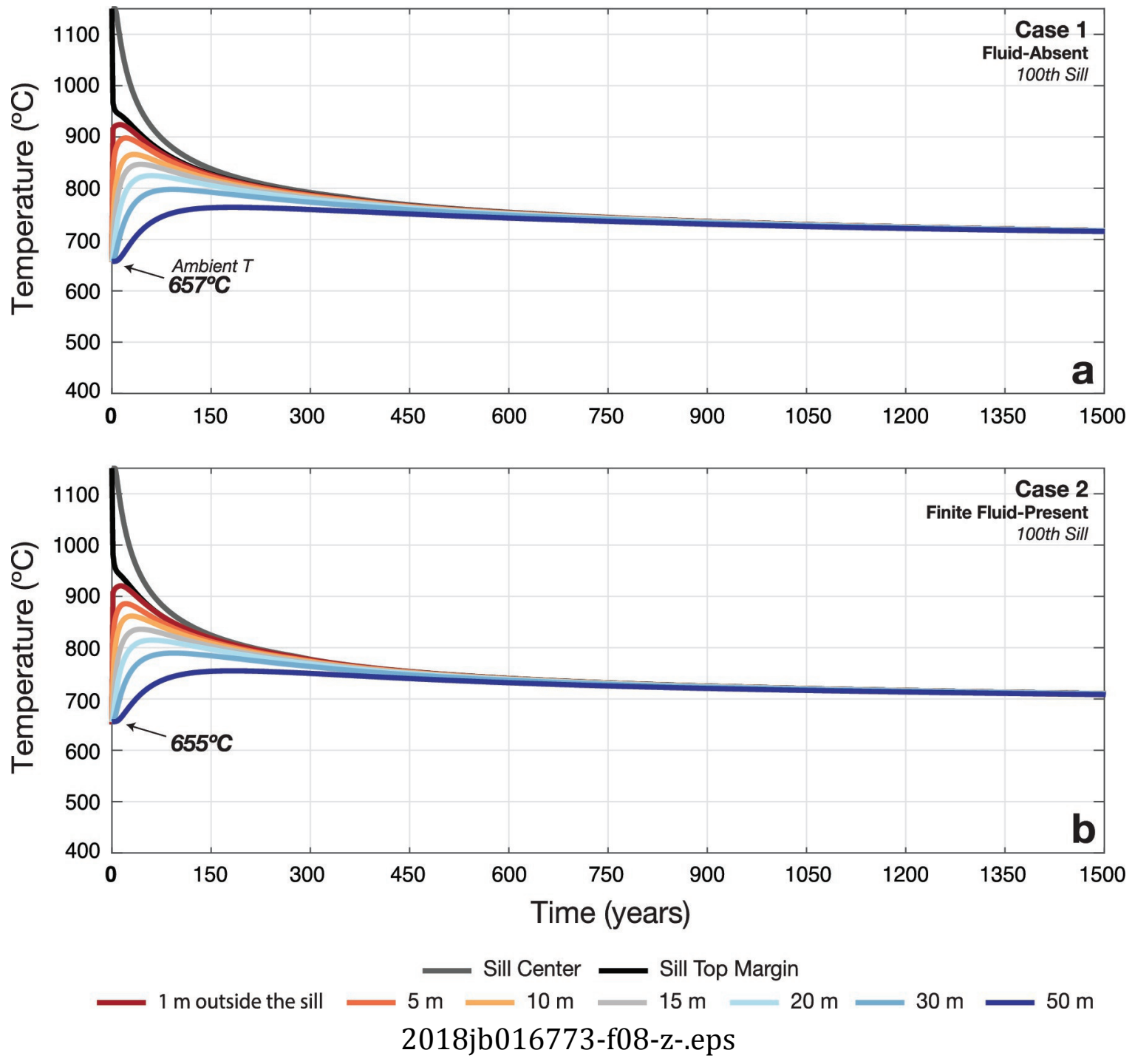

This article is protected by copyright. All rights reserved. 
Ambient T: $420^{\circ} \mathrm{C}$
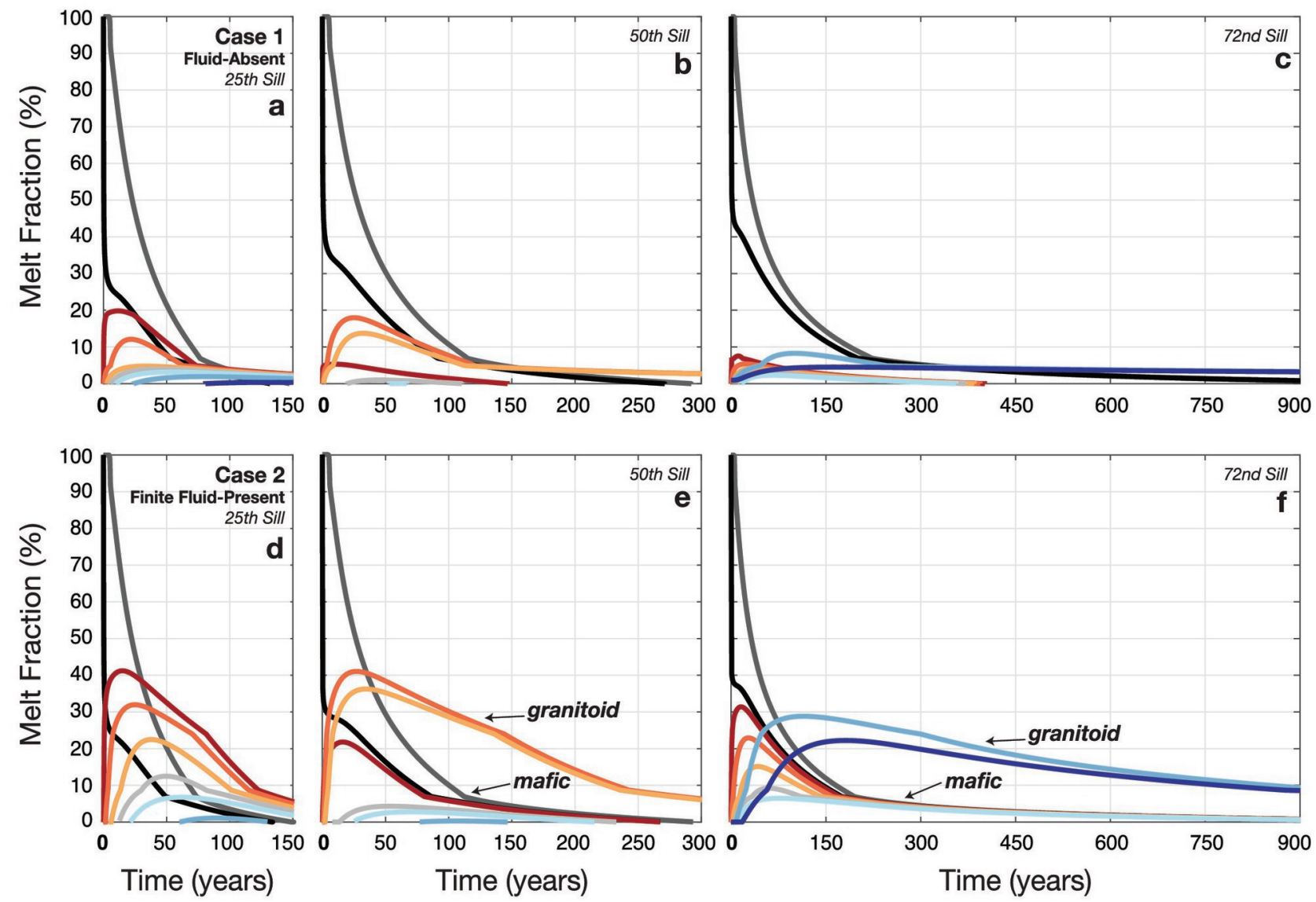

This article is protected by copyright. All rights reserved. 

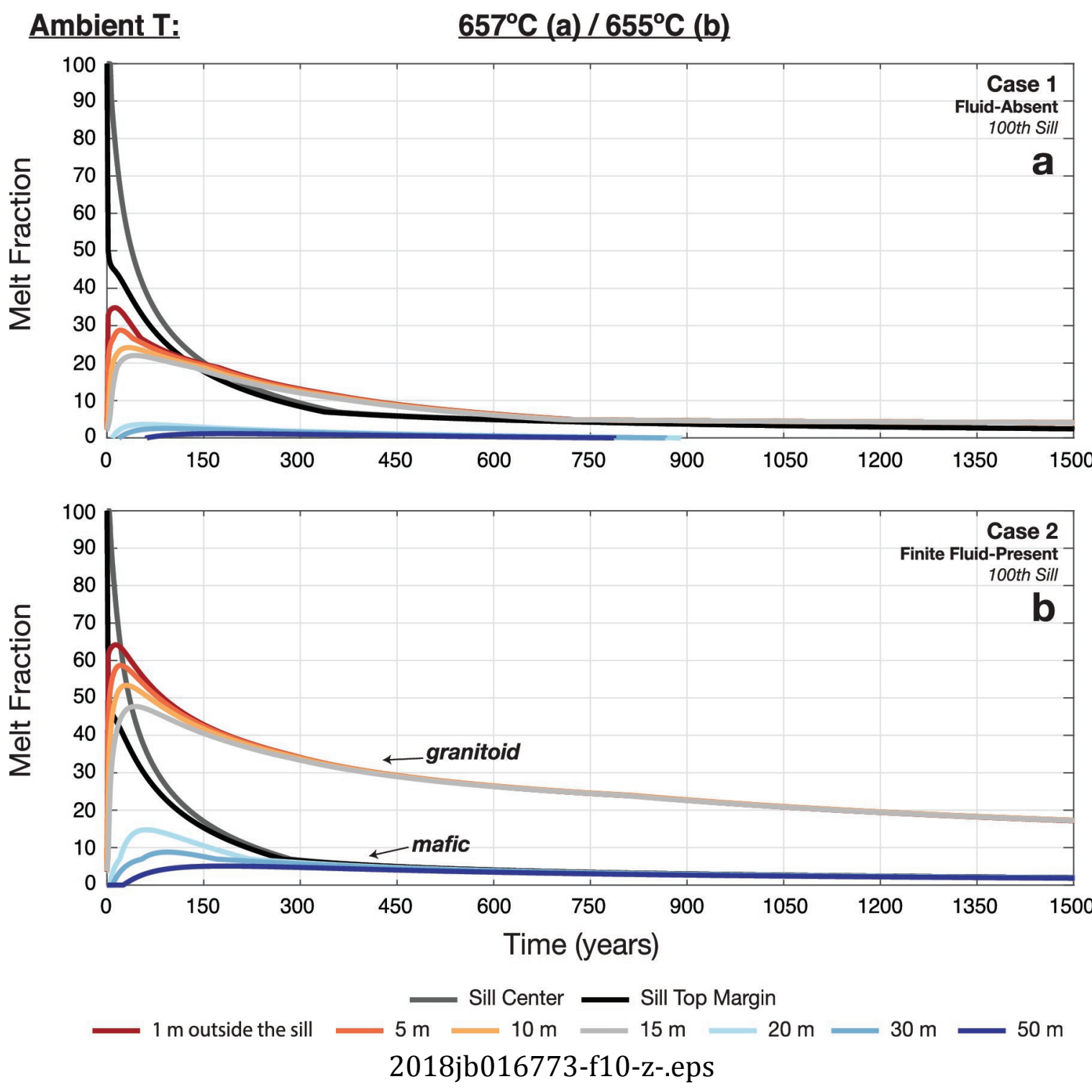

This article is protected by copyright. All rights reserved. 

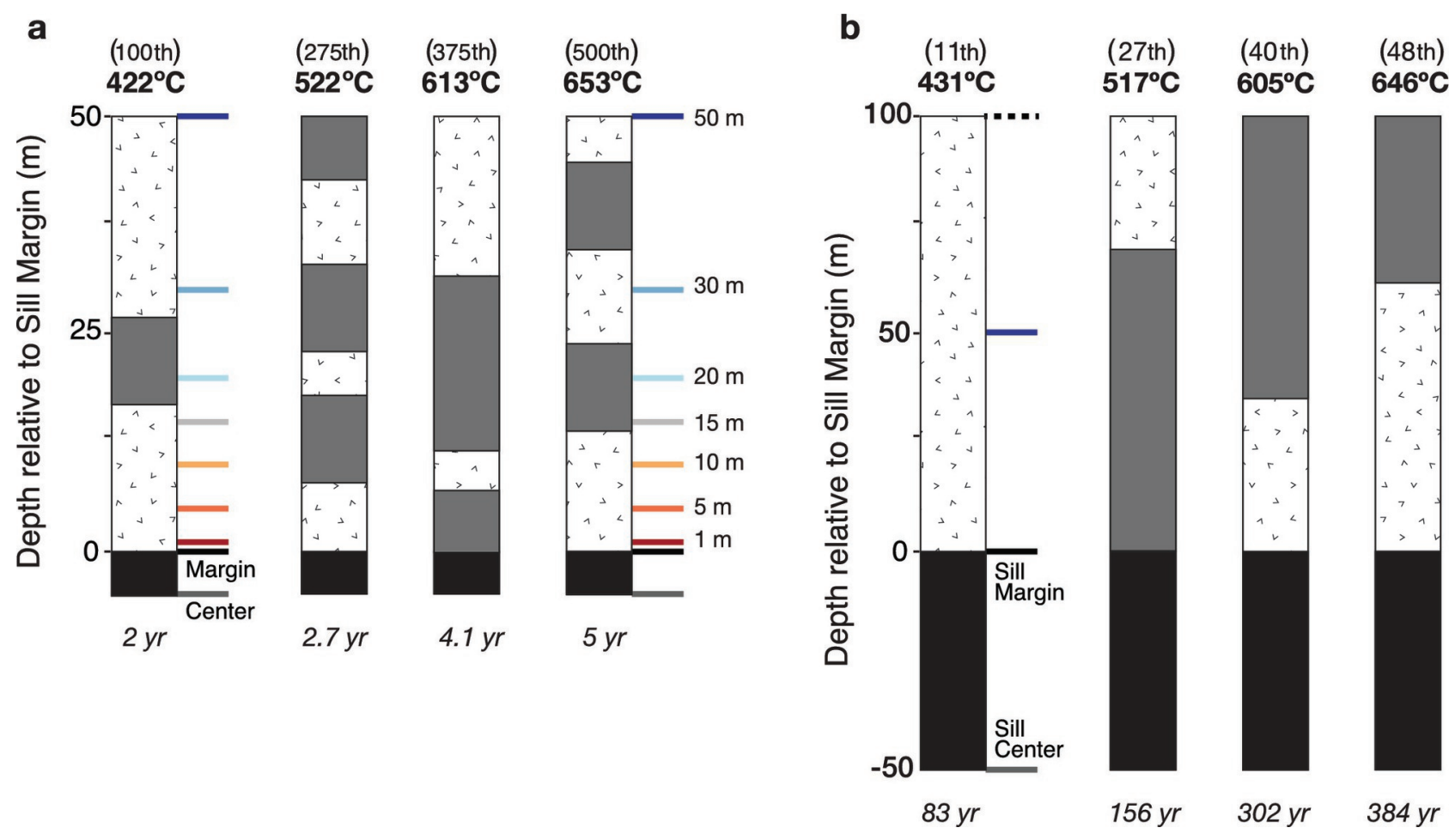

2018jb016773-f11-z-.eps 
Ambient T: $422^{\circ} \mathrm{C}$
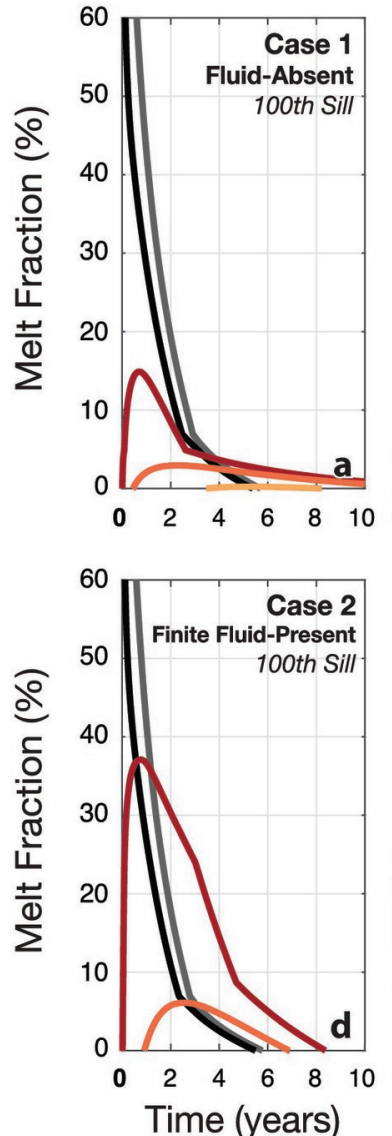

$\underline{521^{\circ} \mathrm{C}}$
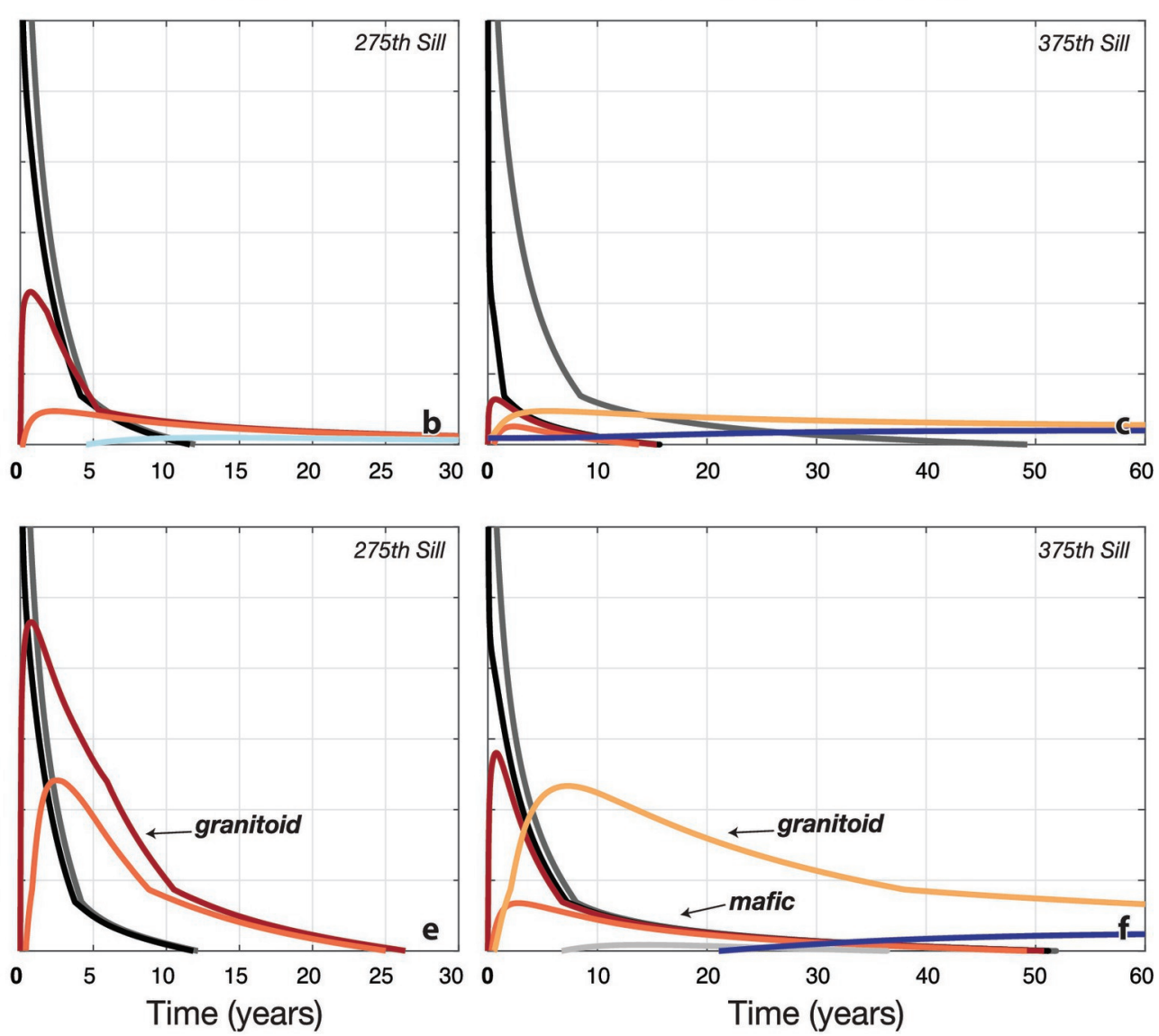

This article is protected by copyright. All rights reserved. 
Ambient T: $\quad 431^{\circ} \mathrm{C}$
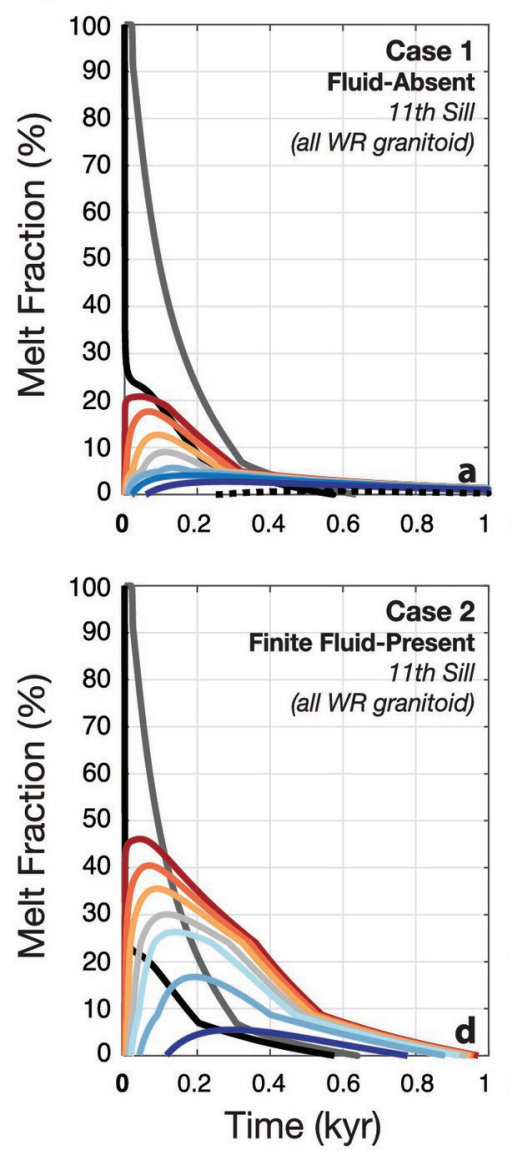

$\underline{517^{\circ} \mathrm{C}}$
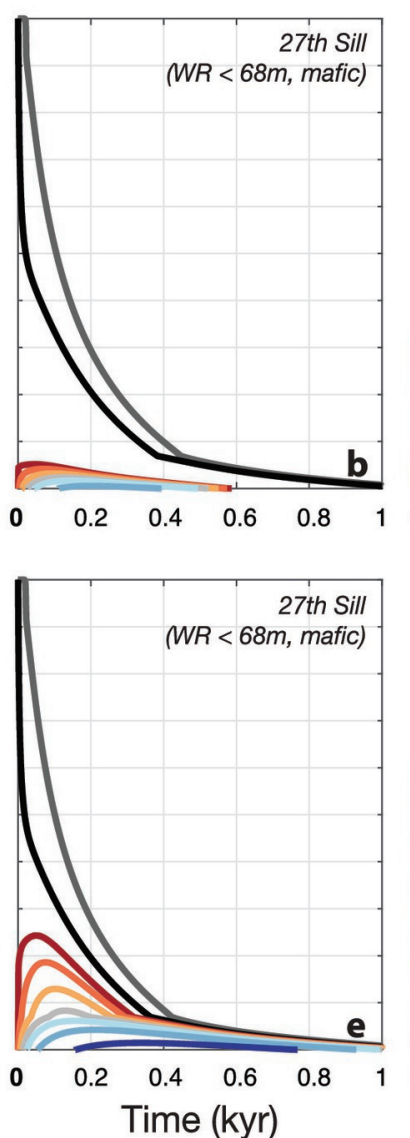

$605^{\circ} \mathrm{C}$
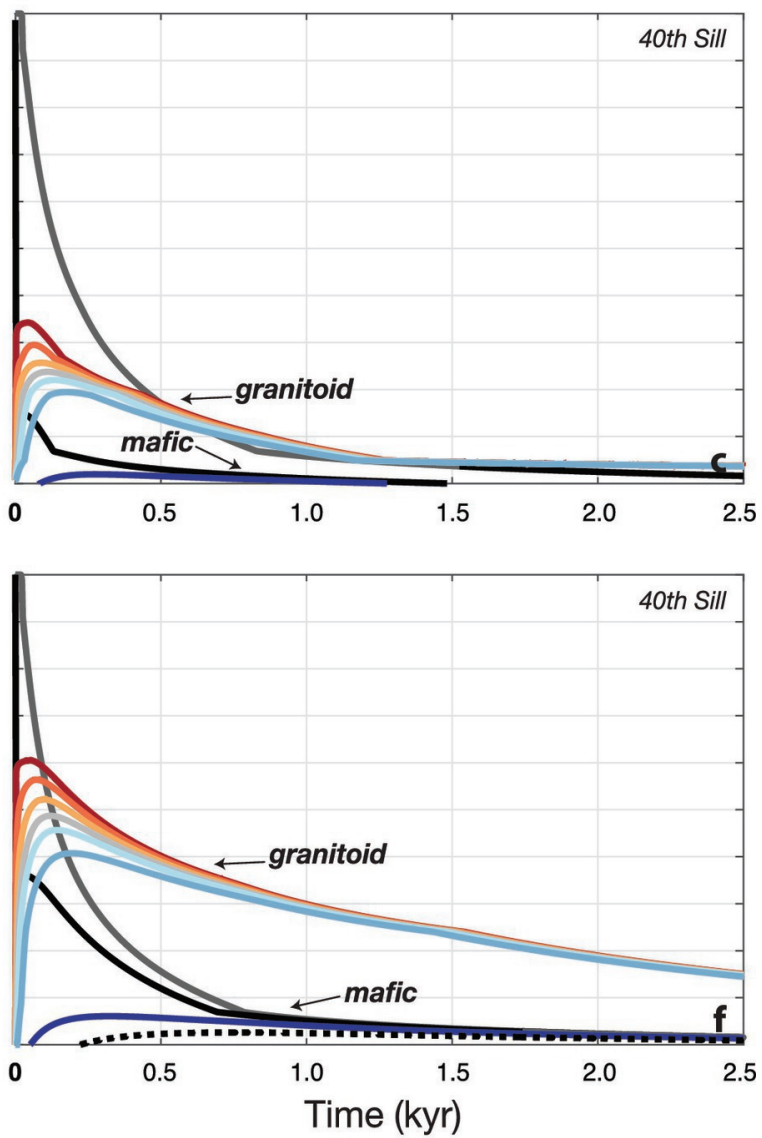

Sill Top Margin $30 \mathrm{~m}-50 \mathrm{~m} \ldots . . .100 \mathrm{~m}$ 

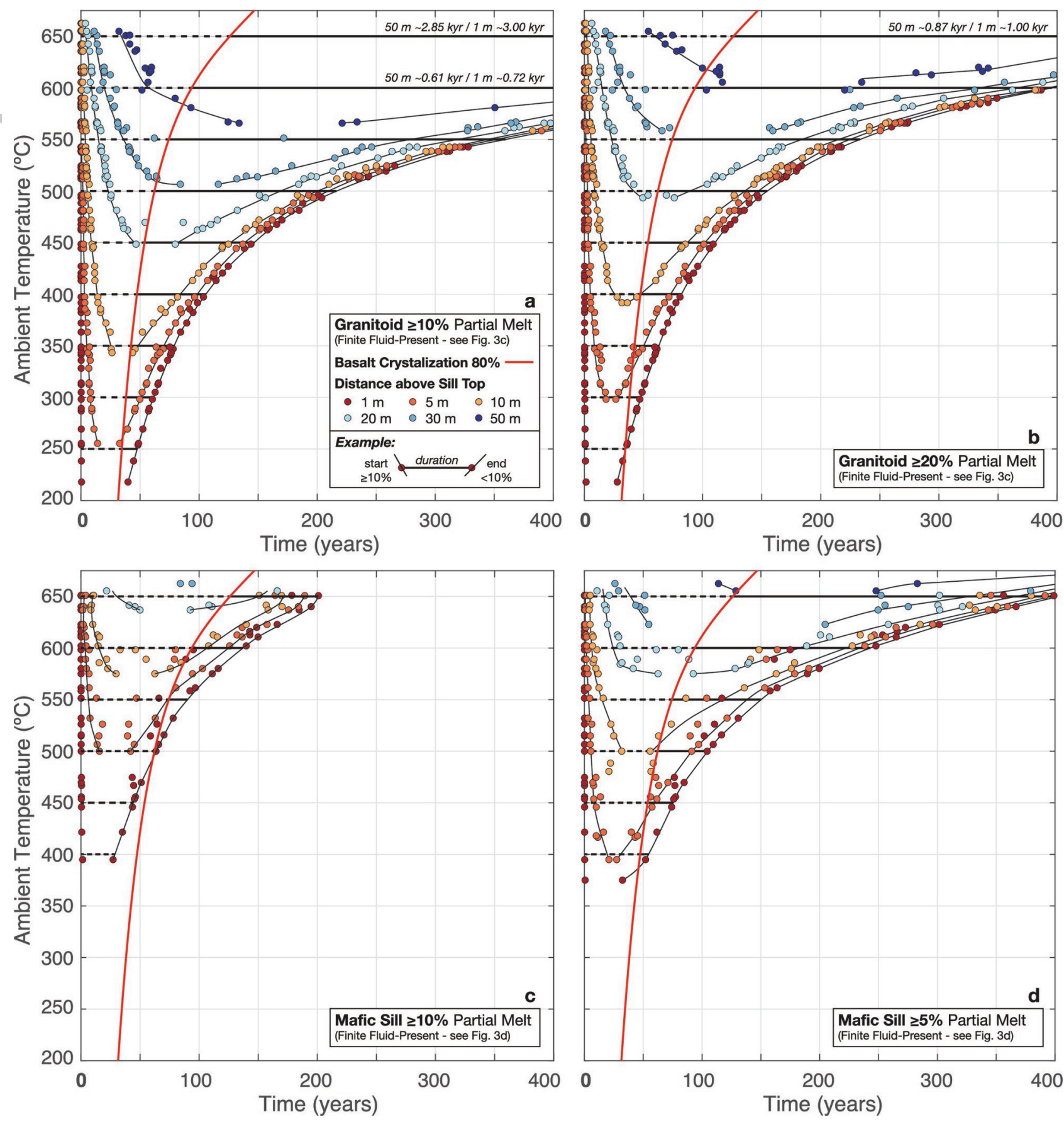

2018jb016773-f14-z-.eps

This article is protected by copyright. All rights reserved. 

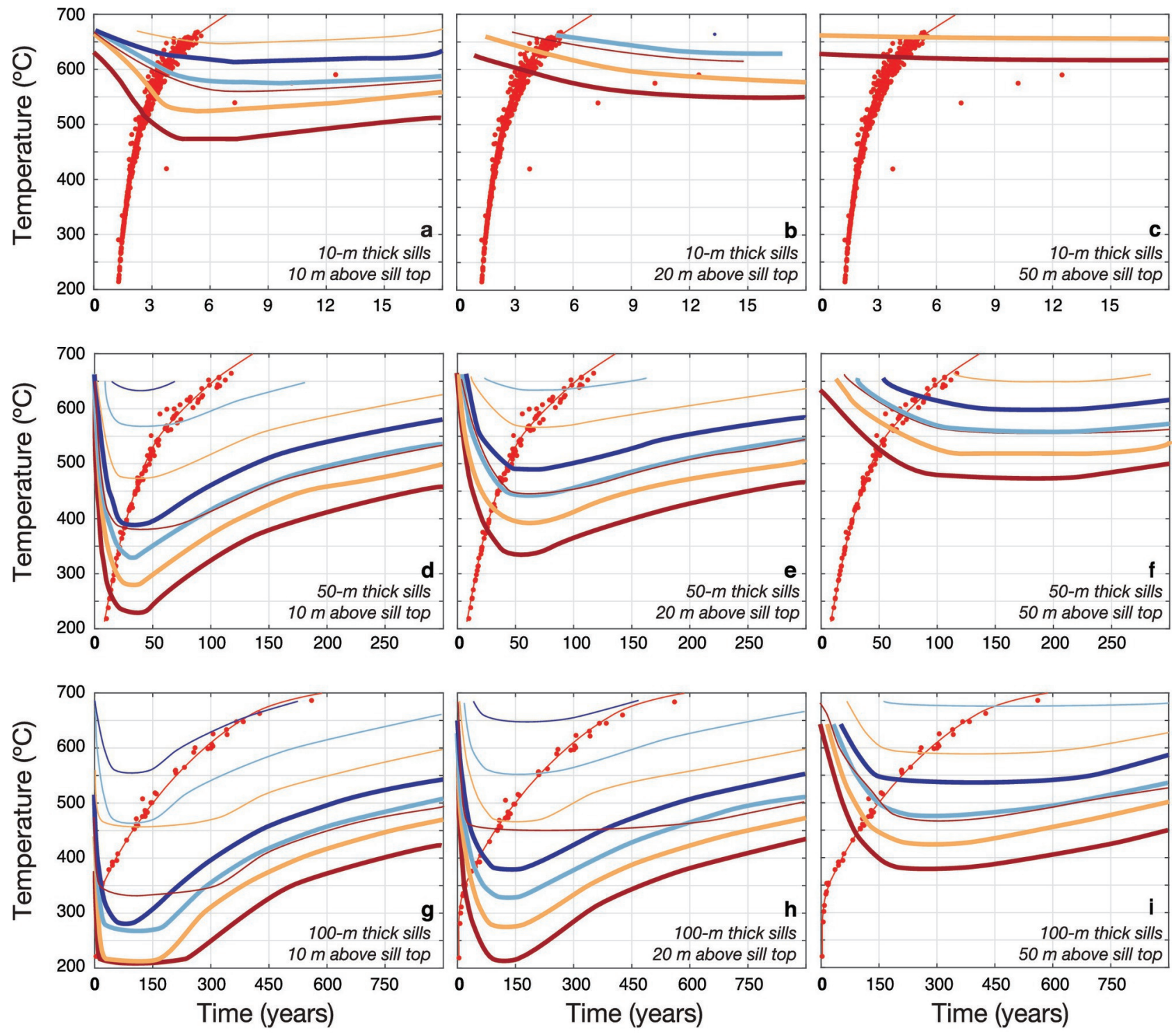

- $80 \%$ Crystallization of Sill Center

$=>0 \%$ Partial Melt at depth $=>5 \%=>10 \%=>20 \%$

2018jb016773-f15-z-.eps

This article is protected by copyright. All rights reserved. 